Supporting Information:

\title{
Quantum Dot-Based Sensitization System for Boosted Photon Absorption and Enhanced Second Near-Infrared Luminescence of Lanthanide-Doped Nanoparticle
}

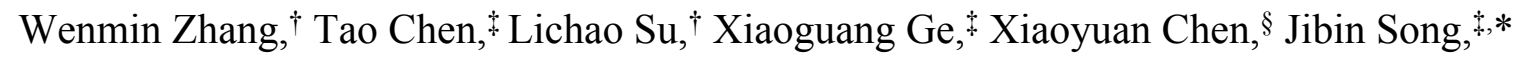
Huanghao Yang*,*

${ }^{\dagger}$ College of Chemical Engineering, Fuzhou University, Fuzhou, Fujian, 350116, P. R. China.

¥MOE Key Laboratory for Analytical Science of Food Safety and Biology, College of

Chemistry, Fuzhou University, Fuzhou, Fujian, 350116, P. R. China.

$\S$ Laboratory of Molecular Imaging and Nanomedicine (LOMIN), National Institute of

Biomedical Imaging and Bioengineering (NIBIB), National Institutes of Health (NIH),

Bethesda, MD 20892 USA

E-mail: jibinsong@,fzu.edu.cn (J. Song); hhyang@,fzu.edu.cn (H. Yang) 


\section{Table of Contents}

Figure S1. Size distribution of the synthesized $\mathrm{Er}^{3+}$-doped LNP ..........................................

Figure S2. Size distribution of the synthesized $\mathrm{Ag}_{2} \mathrm{~S}$ QDs...................................................

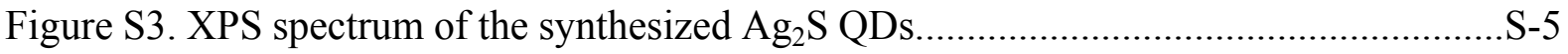

Figure S4. XRD pattern of the synthesized $\mathrm{Ag}_{2} \mathrm{~S}$ QDs.......................................................

Figure S5. Elemental mapping of $\mathrm{Ag}_{2} \mathrm{~S}$ QD-sensitized $\mathrm{Er}^{3+}$-doped LNP hybrid....................S-6

Figure S6. ${ }^{2} \mathrm{~F}_{5 / 2} \rightarrow{ }^{2} \mathrm{~F}_{7 / 2}\left(\mathrm{Yb}^{3+}\right)$ emission spectra of QD-sensitized LNP and bare LNP..........S-7

Figure S7. Fluorescence spectra of QD-sensitized LNP and bare LNP under different laser

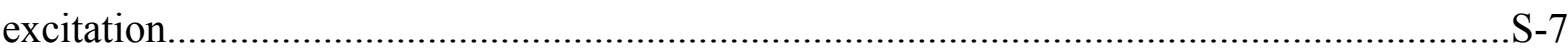

Supplementary method for $\mathrm{Tm}^{3+}$-doped LNPs synthesis................................................

Figure S8. Characterization of the synthesized $\mathrm{Tm}^{3+}$-doped LNPs..................................... -8

Figure S9. TEM image of $\mathrm{Ag}_{2} \mathrm{~S}$ QD-sensitized $\mathrm{Tm}^{3+}$-doped LNPs system........................... -9

Figure S10. Fluorescence and absorption spectra of $\mathrm{Ag}_{2} \mathrm{~S}$ QDs and $\mathrm{Tm}^{3+}$-doped LNPs........S-9

Figure S11. Schematic diagram of proposed energy transfer landscape...............................

Figure S12. Fluorescence spectra of QD-sensitized $\mathrm{Tm}^{3+}$-doped LNP system......................

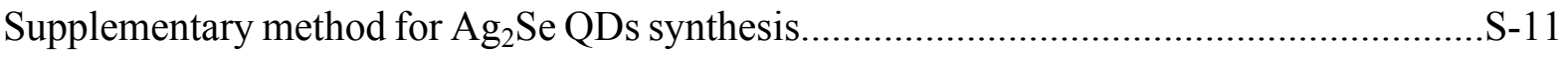

Figure S13. Characterization of the synthesized $\mathrm{Ag}_{2} \mathrm{Se}$ QDs.......................................... -11

Figure S14. Fluorescence and absorption spectra of $\mathrm{Ag}_{2} \mathrm{Se}$ QDs and $\mathrm{Er}^{3+}$-doped LNPs......S-12

Figure S15. Fluorescence spectra of $\mathrm{Ag}_{2} \mathrm{Se}$ QD-sensitized $\mathrm{Er}^{3+}$-doped LNP system............S-12

Supplementary method for $\mathrm{Nd}^{3+}$-doped LNPs synthesis..................................................

Figure S16. Characterization of the synthesized $\mathrm{Nd}^{3+}$-doped LNPs.................................... 13

Figure S17. Fluorescence spectra of $\mathrm{Ag}_{2} \mathrm{~S}$ QD-sensitized $\mathrm{Nd}^{3+}$-doped LNP system............S-14

Figure S18. Fluorescence images of $\mathrm{Nd}^{3+}$-doped LNP and $\mathrm{Yb}^{3+}$-doped LNP under $808 \mathrm{~nm}$ laser

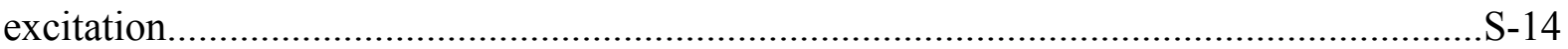

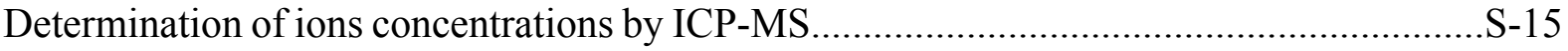

Determination the average surface density of $\mathrm{Ag}_{2} \mathrm{~S}$ QDs on the surface of LNP.................. 15

Calculation of ion contents in the shell of LNPs...................................................................

Figure S19. Working standard curve for quantification of the concentration of $\mathrm{Y}^{3+}$ ions.....S-18 Figure S20. Working standard curve for quantification of the concentration of $\mathrm{Yb}^{3+}$ ions...S-19 Figure S21. Working standard curve for quantification of the concentration of $\mathrm{Er}^{3+}$ ions....S-19 Figure S22. Working standard curve for quantification of the concentration of $\mathrm{Ag}^{+}$ions....S-20 
Figure S23. XRD patterns of core and core-shell LNPs.

Supplementary method for synthesis of core LNPs with $\mathrm{Y}^{3+}$-doped shell

Figure S24. Characterization of the synthesized core-shell LNPs.

Supplementary method for synthesis of core LNPs with $\mathrm{Yb}^{3+}$-doped shell

Figure S25. Characterization of the synthesized core LNPs with $\mathrm{Yb}^{3+}$-doped shell

Figure S26. Fluorescence and absorption spectra of IR-806 dye and $\mathrm{Er}^{3+}$-doped LNPs

Figure S27. Fluorescence spectra of dye-sensitized $\mathrm{Er}^{3+}$-doped LNP system.

Figure S28. Illustration of preparation scheme for $\mathrm{Ag}_{2} \mathrm{~S}$ QDs@mal.....

Figure S29. FI-TR spectrum of the synthesized $\mathrm{Ag}_{2} \mathrm{~S}$ QDs@mal.

Figure S30. Illustration of preparation scheme for LNPs@RP

Figure S31. FI-TR spectrum of the synthesized LNPs@RP

Figure S32. Ex vivo fluorescence spectra based on QD-sensitized LNP system upon GSH treatment.

Supplementary method for tumor retention kinetics of $\mathrm{Ag}_{2} \mathrm{~S} @$ mal QDs.

Figure S33. Tumor retention kinetics of $\mathrm{Ag}_{2} \mathrm{~S} @$ mal QDs....

Supplementary method for tumor retention kinetics of LNPs@RP

Figure S34. Tumor retention kinetics of LNPs@RP

Supplementary method for PbS QDs synthesis.....

Figure S35. Characterization of the synthesized PbS QDs.

Figure S36. Fluorescence and absorption spectra of PbS QDs and $\mathrm{Er}^{3+}$-doped LNPs.

Figure S37. Fluorescence spectra of PbS QD-sensitized $\mathrm{Er}^{3+}$-doped LNP system 


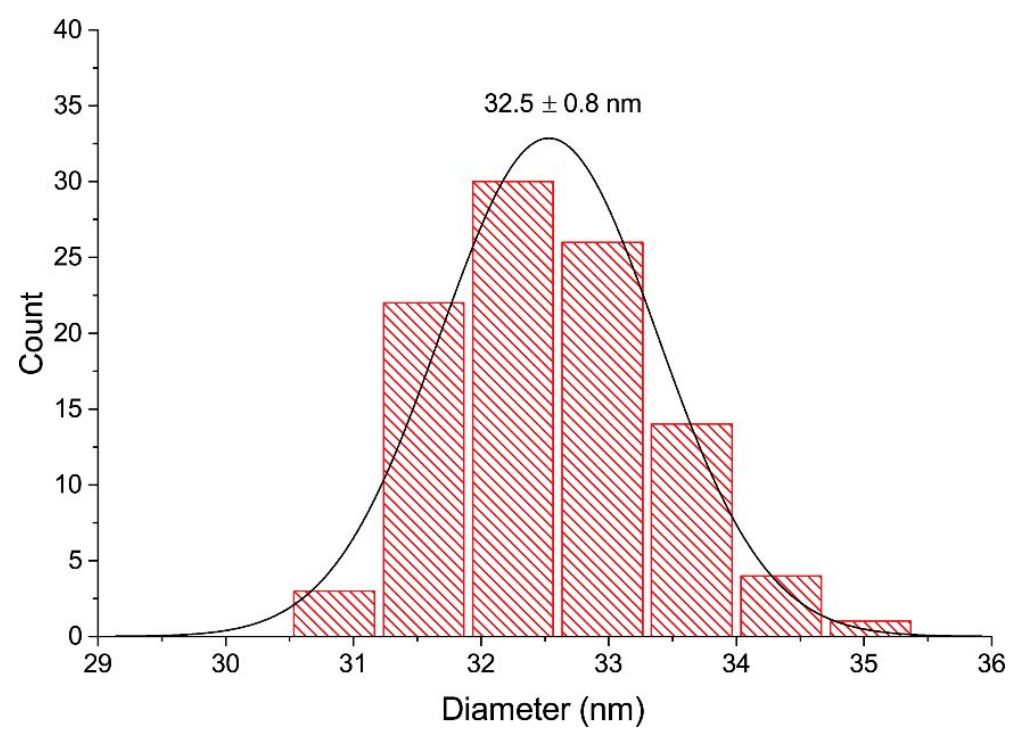

Figure S1. Size distribution of the synthesized $\mathrm{Er}^{3+}$-doped LNPs.

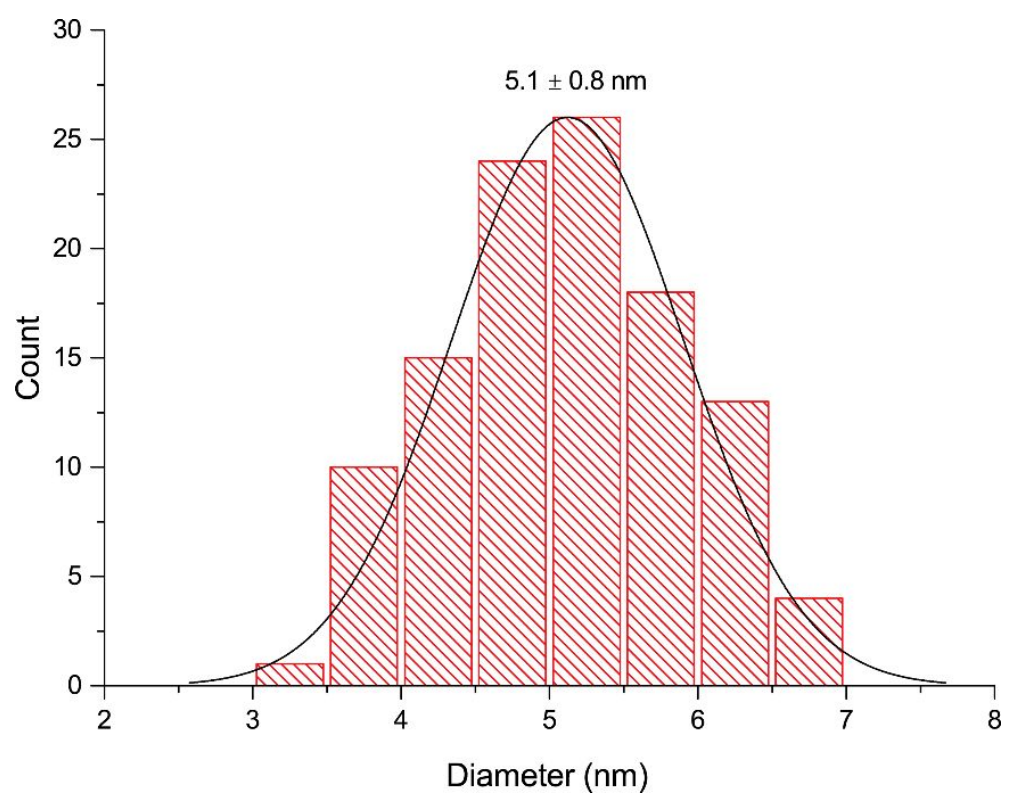

Figure S2. Size distribution of the synthesized $\mathrm{Ag}_{2} \mathrm{~S}$ QDs. 

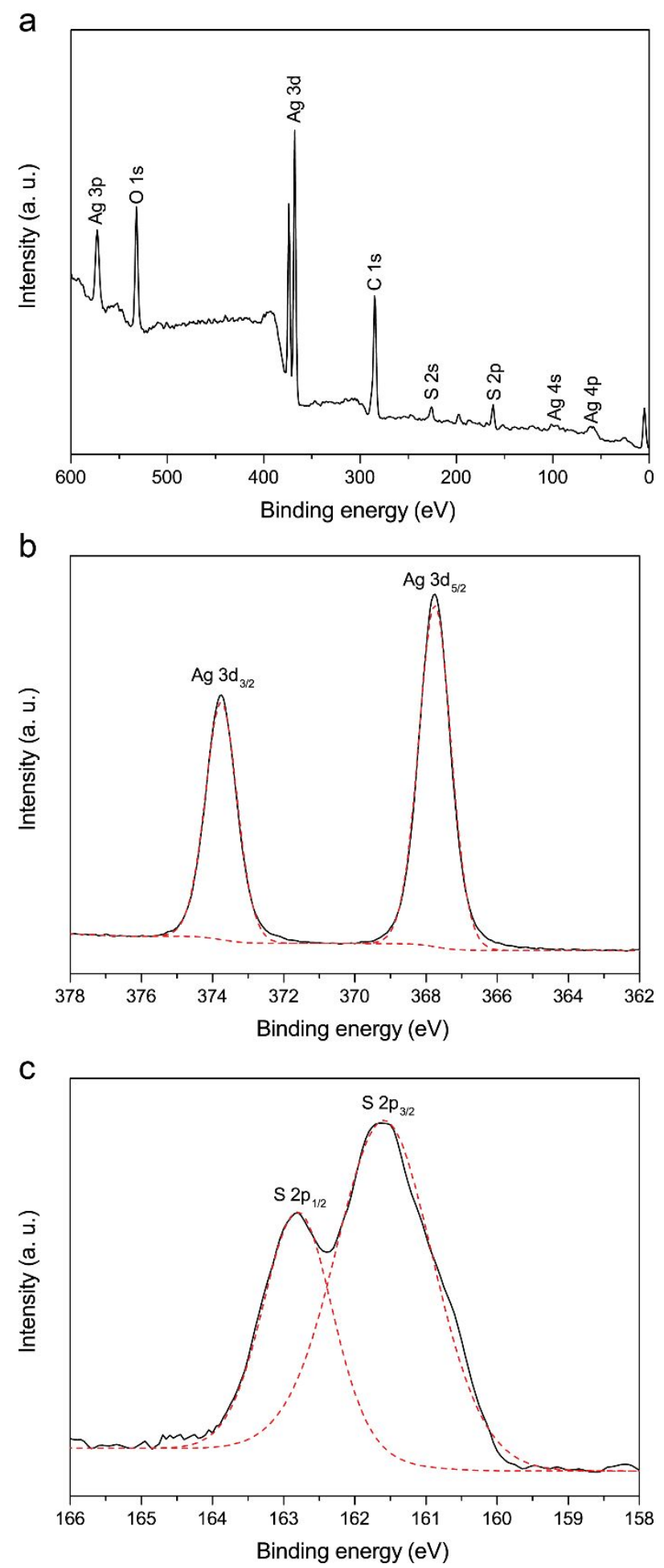

Figure S3. XPS spectrum of the synthesized $\mathrm{Ag}_{2} \mathrm{~S}$ QDs. a) The survey spectra of $\mathrm{Ag}_{2} \mathrm{~S}$ QDs. b) The corresponding high-resolution spectra of $\mathrm{Ag}(3 \mathrm{~d})$, representing the binding energy of $\mathrm{Ag}^{+}$in $\mathrm{Ag}_{2} \mathrm{~S}$. c) The corresponding high-resolution spectra of $\mathrm{S}(2 \mathrm{p})$, representing the binding energy of $\mathrm{S}^{2+}$ in $\mathrm{Ag}_{2} \mathrm{~S}$. 


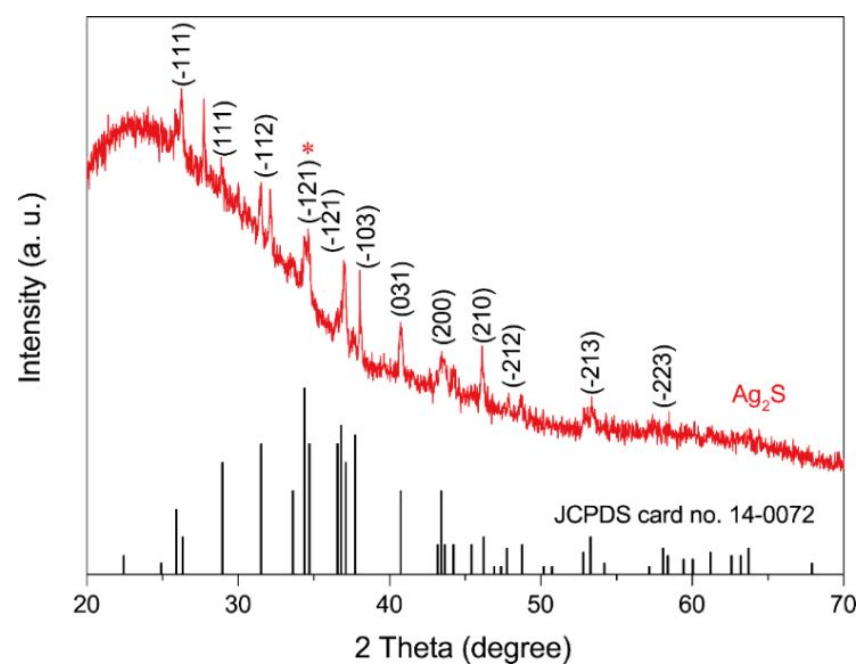

Figure S4. XRD pattern of the synthesized $\mathrm{Ag}_{2} \mathrm{~S}$ QDs. The result shows the position and relative intensity of diffraction peaks of the synthesized $\mathrm{Ag}_{2} \mathrm{~S}$ QDs were in accordance with those of standard monoclinic $\mathrm{Ag}_{2} \mathrm{~S}$ (JCPDS card no. 14-0072).

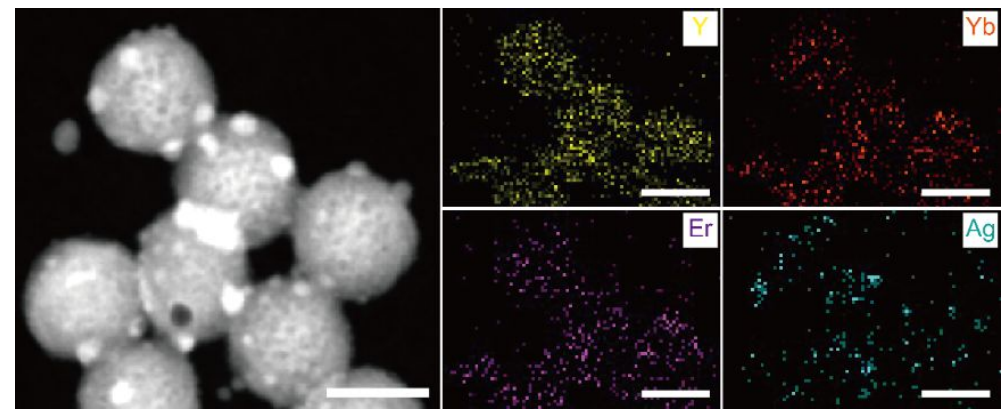

Figure S5. Elemental mapping of $\mathrm{Ag}_{2} \mathrm{~S}$ QD-sensitized $\mathrm{Er}^{3+}$-doped LNP hybrid including $\mathrm{Y}$, $\mathrm{Yb}, \mathrm{Er}$, and Ag elements. The QD-sensitized LNP hybrid was obtained by incubating $60 \mu \mathrm{L}$ of $\mathrm{Er}^{3+}$-doped LNP $\left(20 \mathrm{mg} \mathrm{mL}^{-1}\right)$ with $600 \mu \mathrm{L}$ of $\mathrm{Ag}_{2} \mathrm{~S}$ QDs $\left(\mathrm{OD}_{808}=0.6\right)$. Scale bar, $50 \mathrm{~nm}$. 


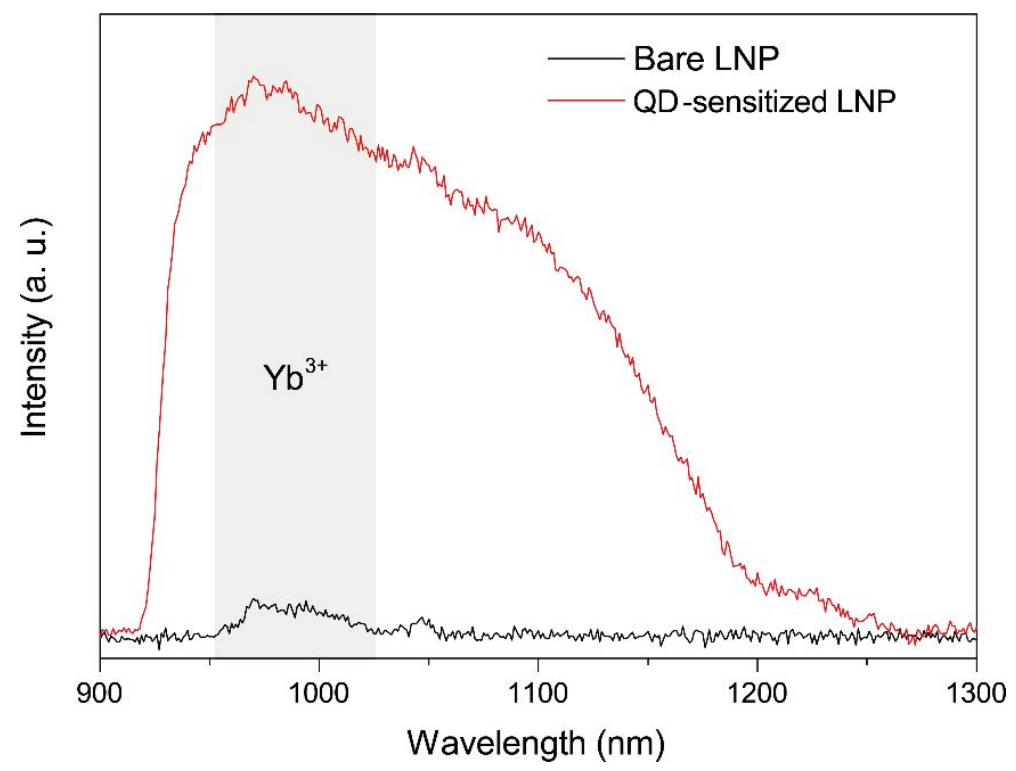

Figure S6. ${ }^{2} \mathrm{~F}_{5 / 2} \rightarrow{ }^{2} \mathrm{~F}_{7 / 2}\left(\mathrm{Yb}^{3+}\right)$ emission spectra of QD-sensitized LNP and bare LNP. Emission spectra were obtained from LNP $\left(60 \mu \mathrm{L}, 20 \mathrm{mg} \mathrm{mL}^{-1}\right)$ with/without $\mathrm{Ag}_{2} \mathrm{~S}$ QDs $\left(25 \mu \mathrm{L}, \mathrm{OD}_{808}\right.$ $=0.6)$ sensitization at $808 \mathrm{~nm}(2 \mathrm{~W}$, c.w.) laser excitation.

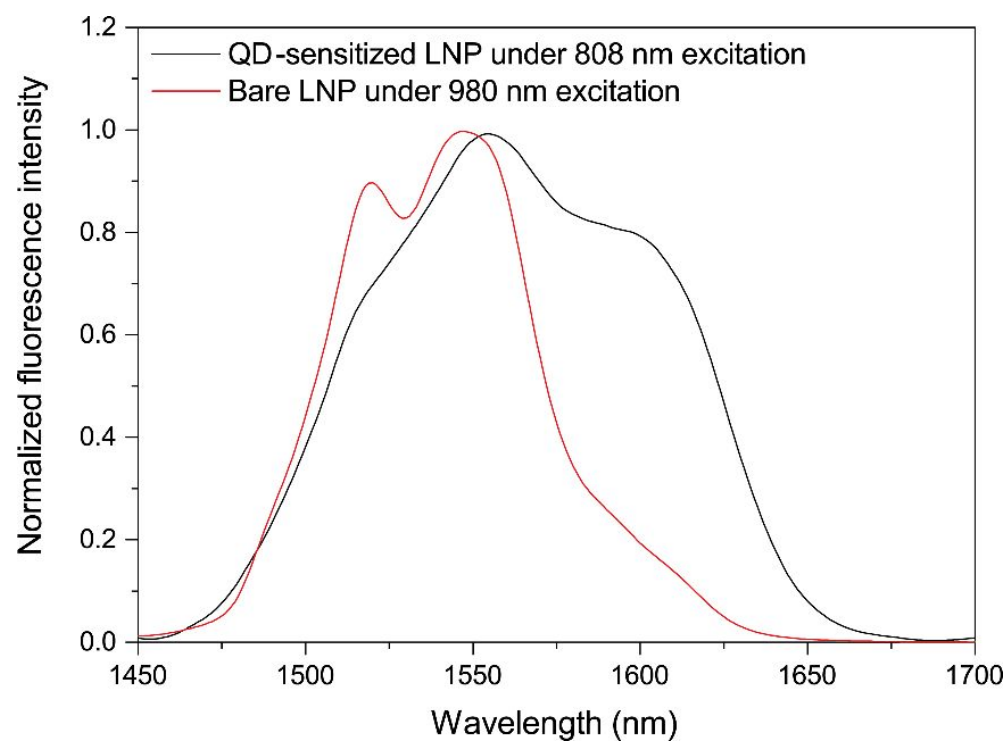

Figure S7. Fluorescence spectra of QD-sensitized LNP and bare LNP under different laser excitation. Fluorescence spectra were obtained from QD-sensitized LNP at $808 \mathrm{~nm}(2 \mathrm{~W}$, c.w.) laser excitation, and bare LNP at $980 \mathrm{~nm}$ ( $2 \mathrm{~W}$, c.w.) laser excitation. 
Synthesis of $\sim 32 \mathrm{~nm} \mathrm{NaY} \mathbf{0 . 7 9 5}_{4} \mathrm{~F}_{4}: \mathbf{Y b}_{0.2}, \mathbf{T m}_{0.005}$ core NPs. The procedure is identical to the synthesis of $\mathrm{NaY}_{0.8} \mathrm{~F}_{4}: \mathrm{Yb}_{0.18}, \mathrm{Er}_{0.02}$ core $\mathrm{NPs}$, except using an aqueous solution $(2 \mathrm{~mL})$ of $\mathrm{Y}\left(\mathrm{CH}_{3} \mathrm{CO}_{2}\right)_{3}(0.795 \mathrm{mmol}), \mathrm{Yb}\left(\mathrm{CH}_{3} \mathrm{CO}_{2}\right)_{3}(0.2 \mathrm{mmol}), \mathrm{Tm}\left(\mathrm{CH}_{3} \mathrm{CO}_{2}\right)_{3}(0.005 \mathrm{mmol})$ to replace the aqueous solution $(2 \mathrm{~mL})$ of $\mathrm{Y}\left(\mathrm{CH}_{3} \mathrm{CO}_{2}\right)_{3}(0.78 \mathrm{mmol}), \mathrm{Yb}\left(\mathrm{CH}_{3} \mathrm{CO}_{2}\right)_{3}(0.2 \mathrm{mmol})$, $\mathrm{Er}\left(\mathrm{CH}_{3} \mathrm{CO}_{2}\right)_{3}(0.02 \mathrm{mmol})$.
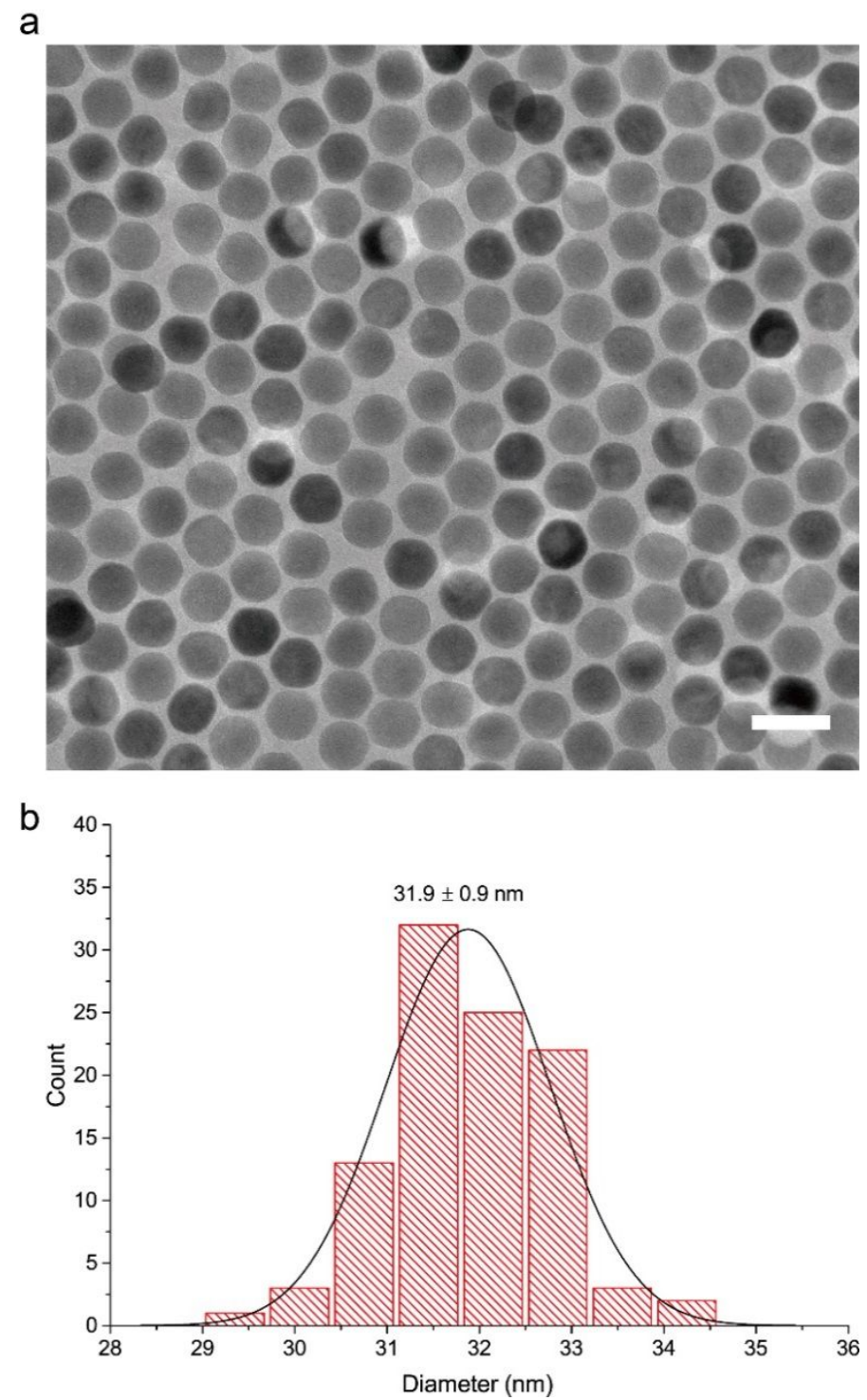

Figure S8. Characterization of the synthesized $\mathrm{Tm}^{3+}$-doped LNPs. a) TEM image of the synthesized $\mathrm{Tm}^{3+}$-doped LNPs. Scale bar, $50 \mathrm{~nm}$. b) Size distribution of the synthesized $\mathrm{Tm}^{3+}{ }_{-}$ doped LNPs. 


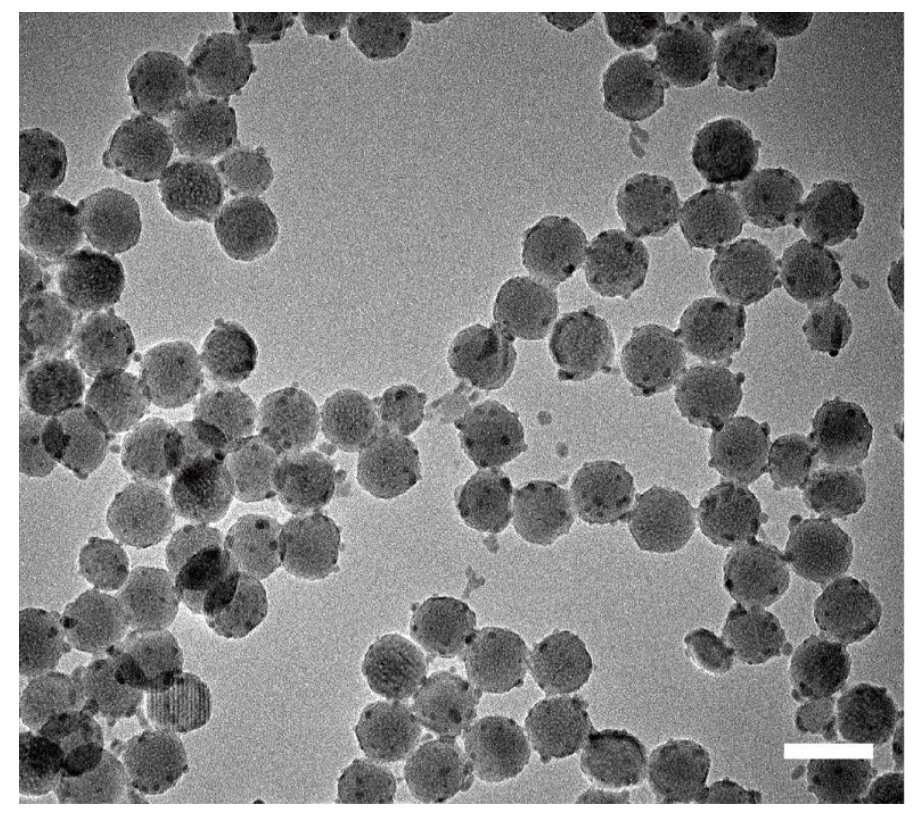

Figure S9. TEM image of $\mathrm{Ag}_{2} \mathrm{~S}$ QD-sensitized $\mathrm{Tm}^{3+}$-doped LNPs system. The relatively largesized $\mathrm{Tm}^{3+}$-doped LNPs served as a nanoscale scaffold for decorating multiple copies of $\mathrm{Ag}_{2} \mathrm{~S}$ QDs. Scale bar, $50 \mathrm{~nm}$.

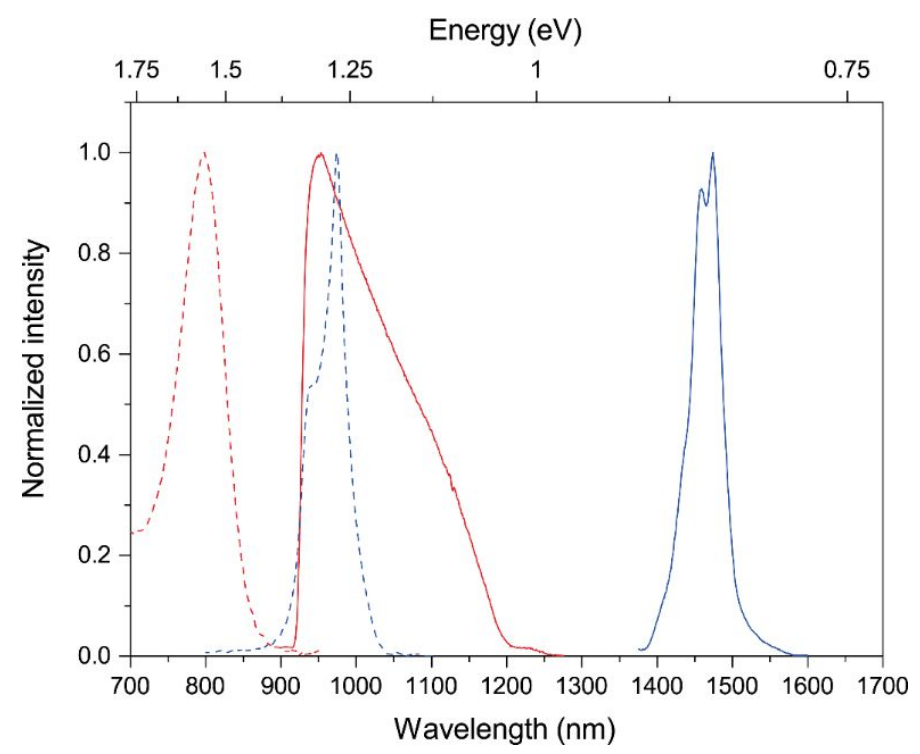

Figure S10. Fluorescence and absorption spectra of $\mathrm{Ag}_{2} \mathrm{~S}$ QDs and $\mathrm{Tm}^{3+}$-doped LNPs. Spectra from left to right, coloured according to their transitions in Figure S12: $\mathrm{Ag}_{2} \mathrm{~S}$ QDs adsorption (dashed red line), $\mathrm{Ag}_{2} \mathrm{~S}$ QDs fluorescence (solid red line) at $808 \mathrm{~nm}$ (2 W, c.w.) laser excitation, $\mathrm{Tm}^{3+}$-doped LNPs absorption (dashed blue line) and $\mathrm{Tm}^{3+}$-doped LNPs fluorescence (solid blue line) at $980 \mathrm{~nm}(2 \mathrm{~W}, \mathrm{c.w}$.$) laser excitation.$ 


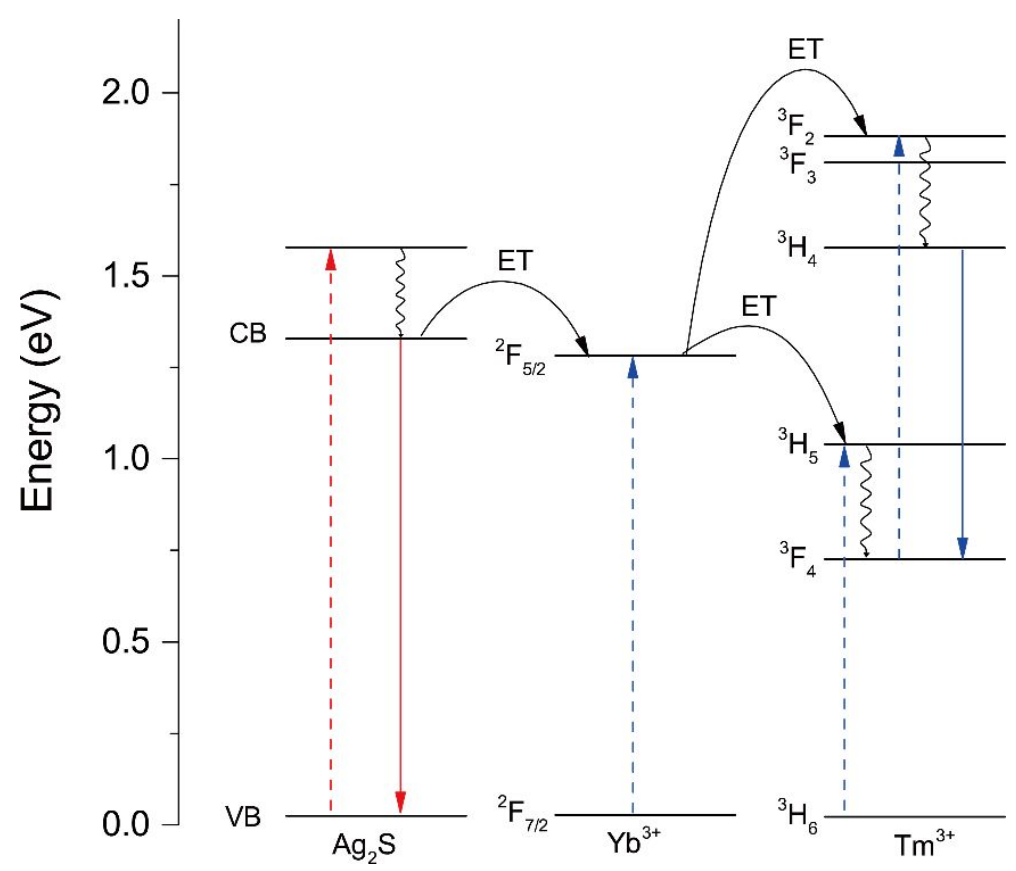

Figure S11. Schematic diagram of proposed energy transfer landscape. The picture shows $\mathrm{Ag}_{2} \mathrm{~S}$ QDs transfer energy to lanthanide ion pair $\left(\mathrm{Yb}^{3+} / \mathrm{Tm}^{3+}\right)$ in LNP, and emission from LNP.

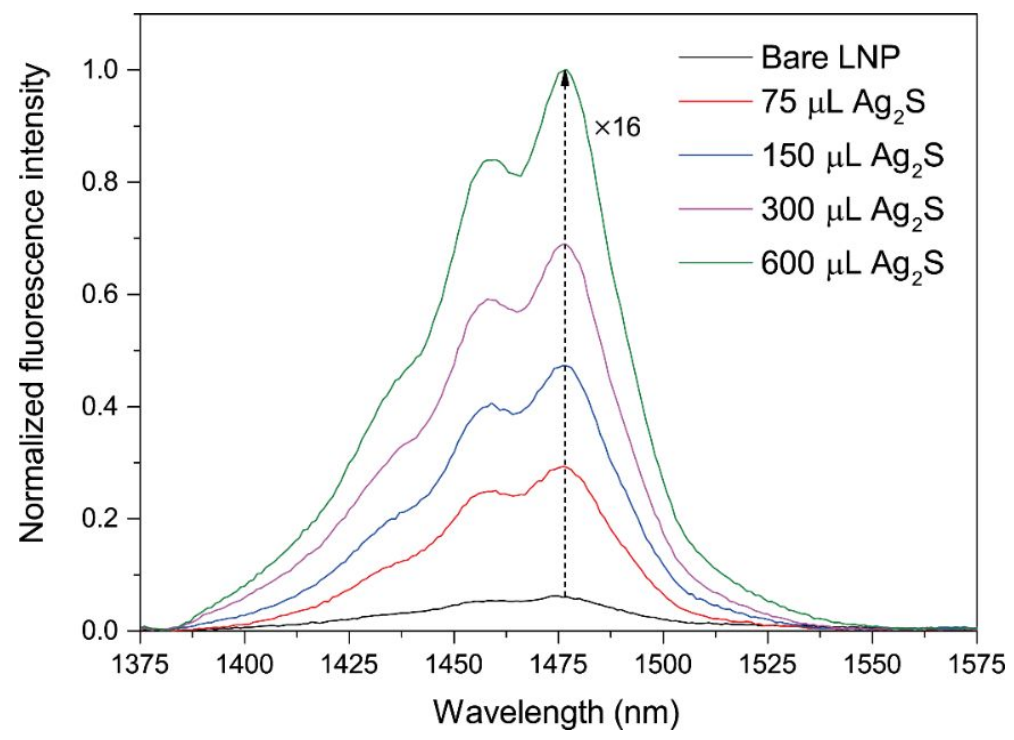

Figure S12. Fluorescence spectra of QD-sensitized $\mathrm{Tm}^{3+}$-doped LNP system. With increasing amounts of $\mathrm{Ag}_{2} \mathrm{~S}$ QDs $\left(\mathrm{OD}_{808}=0.6\right)$, the emission intensity of $\mathrm{Tm}^{3+}$-doped LNPs $(60 \mu \mathrm{L}, 20$ $\left.\mathrm{mg} \mathrm{mL} \mathrm{mL}^{-1}\right)$ increased under $808 \mathrm{~nm}(2 \mathrm{~W}$, c.w.) laser excitation. 
Synthesis of $\mathrm{Ag}_{2} \mathrm{Se}$ QDs. $0.1 \mathrm{mmol}$ of $\mathrm{CH}_{3} \mathrm{COOAg}, 286 \mu \mathrm{L}$ of 1-octanethiol was added into 5 $\mathrm{mL}$ of ODE in a $50 \mathrm{~mL}$ three-neck bottom flask under argon atmosphere. Subsequently, 0.1 mmol of Se dissolved in TOP $(1.5 \mathrm{~mL})$ was injected rapidly into the mixture at $160{ }^{\circ} \mathrm{C}$ under vigorous stirring. The reaction then was quickly terminated in an ice-water bath. The resulting product was precipitated by addition of acetone, collected by centrifugation at $10000 \mathrm{rpm}$ for $3 \mathrm{~min}$, and then dispersed in $1 \mathrm{~mL}$ of cyclohexane. Finally, the obtained $\mathrm{Ag}_{2} \mathrm{Se}$ QDs was mixed with an ethanol solution containing mercaptoundecanoic acid. After stirred overnight at room temperature, the resulting product was centrifuged at $10000 \mathrm{rpm}$ for $20 \mathrm{~min}$, and washed with ethanol/deionized water several times. The product was redispersed in Tris- $\mathrm{HCl}$ buffer $(0.01$ $\mathrm{M}, \mathrm{pH} 7.4$ ), and stored at $4{ }^{\circ} \mathrm{C}$ in the dark for further use.

a
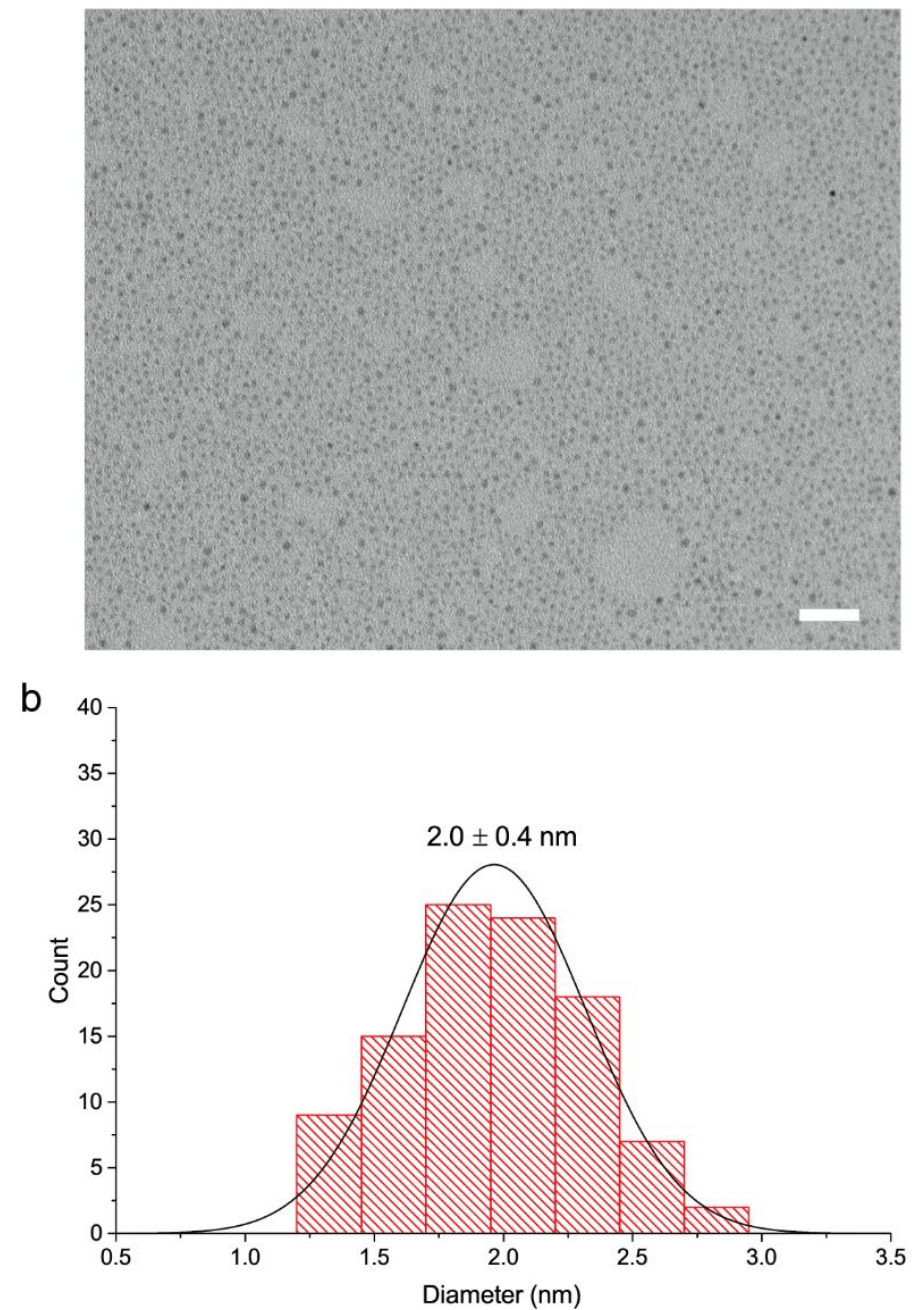
Figure S13. Characterization of the synthesized $\mathrm{Ag}_{2} \mathrm{Se}$ QDs. a) TEM image of the synthesized $\mathrm{Ag}_{2} \mathrm{Se}$ QDs. Scale bar, $25 \mathrm{~nm}$. b) Size distribution of the synthesized $\mathrm{Ag}_{2} \mathrm{Se}$ QDs.

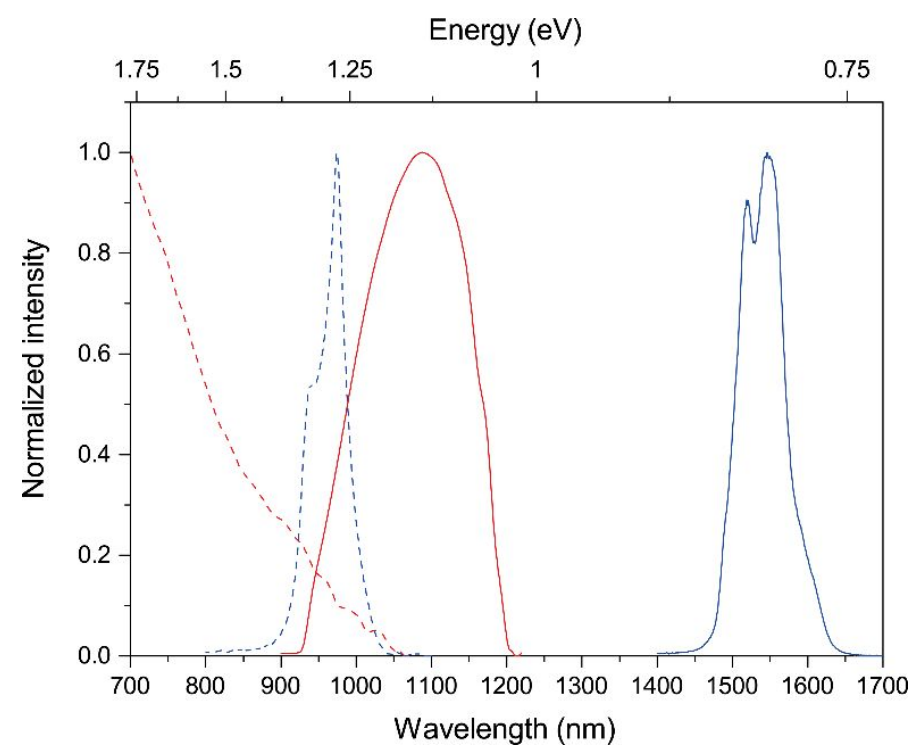

Figure S14. Fluorescence and absorption spectra of $\mathrm{Ag}_{2} \mathrm{Se}$ QDs and $\mathrm{Er}^{3+}$-doped LNPs. Spectra from left to right: $\mathrm{Ag}_{2} \mathrm{Se}$ QDs adsorption (dashed red line), $\mathrm{Ag}_{2} \mathrm{Se}$ QDs fluorescence (solid red line) at $808 \mathrm{~nm}$ ( $2 \mathrm{~W}$, c.w.) laser excitation, $\mathrm{Er}^{3+}$-doped LNPs absorption (dashed blue line) and $\mathrm{Er}^{3+}$-doped LNPs fluorescence (solid blue line) at $980 \mathrm{~nm}(2 \mathrm{~W}, \mathrm{c.w}$.$) laser excitation.$

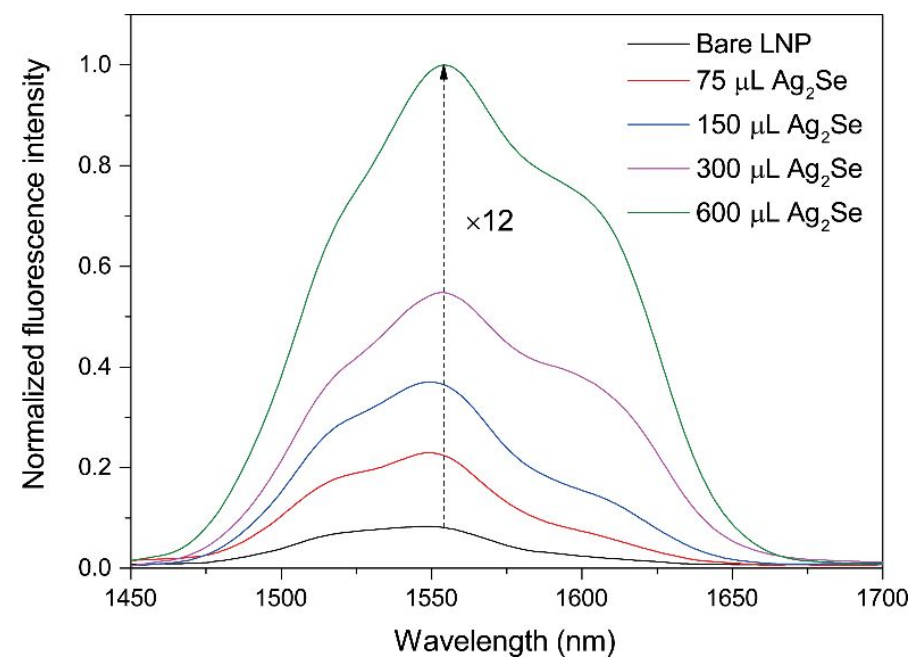

Figure S15. Fluorescence spectra of $\mathrm{Ag}_{2} \mathrm{Se}$ QD-sensitized $\mathrm{Er}^{3+}$-doped LNP system. With increasing amounts of $\mathrm{Ag}_{2} \mathrm{Se}$ QDs $\left(\mathrm{OD}_{808}=0.6\right)$, the emission intensity of $\mathrm{Er}^{3+}$-doped LNPs $\left(60 \mu \mathrm{L}, 20 \mathrm{mg} \mathrm{mL}^{-1}\right)$ increased under $808 \mathrm{~nm}(2 \mathrm{~W}$, c.w.) laser excitation. 
Synthesis of $\sim 32 \mathrm{~nm} \mathrm{NaY}{ }_{0.785} \mathbf{F}_{4}: \mathbf{N d}_{0.01}, \mathbf{Y b}_{0.2}, \mathbf{E r}_{0.005}$ core NPs. The procedure is identical to the synthesis of $\mathrm{NaY}_{0.8} \mathrm{~F}_{4}: \mathrm{Yb}_{0.18}, \mathrm{Er}_{0.02}$ core NPs, except using an aqueous solution $(2 \mathrm{~mL})$ of $\mathrm{Y}\left(\mathrm{CH}_{3} \mathrm{CO}_{2}\right)_{3} \quad(0.785 \mathrm{mmol}), \mathrm{Nd}\left(\mathrm{CH}_{3} \mathrm{CO}_{2}\right)_{3} \quad(0.01 \mathrm{mmol}), \quad \mathrm{Yb}\left(\mathrm{CH}_{3} \mathrm{CO}_{2}\right)_{3} \quad(0.2 \mathrm{mmol})$, $\mathrm{Er}\left(\mathrm{CH}_{3} \mathrm{CO}_{2}\right)_{3}(0.005 \mathrm{mmol})$ to replace the aqueous solution $(2 \mathrm{~mL})$ of $\mathrm{Y}\left(\mathrm{CH}_{3} \mathrm{CO}_{2}\right)_{3}(0.78$ $\mathrm{mmol}), \mathrm{Yb}\left(\mathrm{CH}_{3} \mathrm{CO}_{2}\right)_{3}(0.2 \mathrm{mmol}), \mathrm{Er}\left(\mathrm{CH}_{3} \mathrm{CO}_{2}\right)_{3}(0.02 \mathrm{mmol})$.
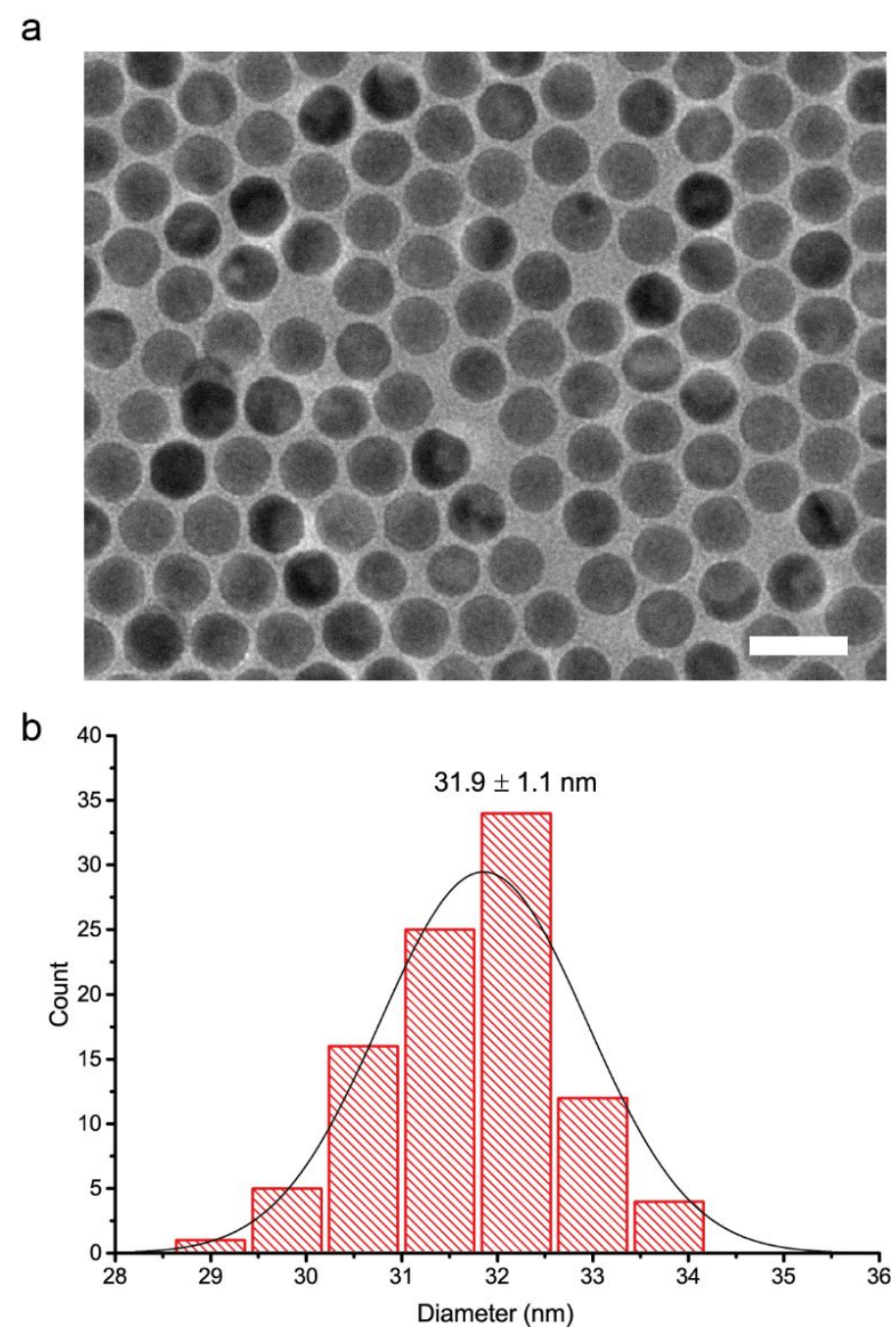

Figure S16. Characterization of the synthesized $\mathrm{Nd}^{3+}$-doped LNPs. a) TEM image of the synthesized $\mathrm{Nd}^{3+}$-doped LNPs. Scale bar, $50 \mathrm{~nm}$. b) Size distribution of the synthesized $\mathrm{Nd}^{3+}-$ doped LNPs. 


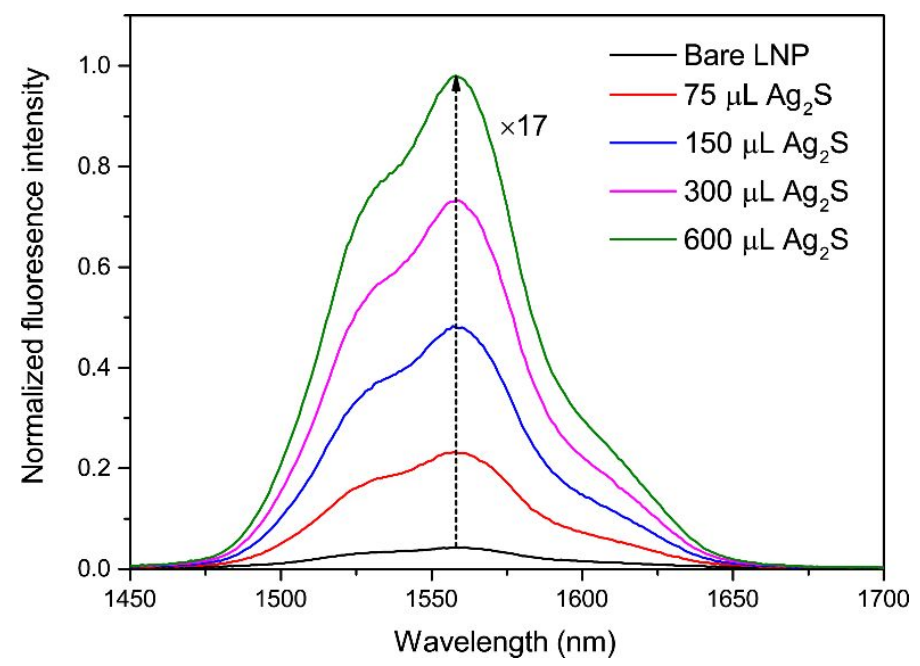

Figure S17. Fluorescence spectra of $\mathrm{Ag}_{2} \mathrm{~S}$ QD-sensitized $\mathrm{Nd}^{3+}$-doped LNP system. With increasing amounts of $\mathrm{Ag}_{2} \mathrm{~S}$ QDs $\left(\mathrm{OD}_{808}=0.6\right)$, the emission intensity of $\mathrm{Nd}^{3+}$-doped LNPs $\left(60 \mu \mathrm{L}, 20 \mathrm{mg} \mathrm{mL}^{-1}\right)$ increased under $808 \mathrm{~nm}(2 \mathrm{~W}$, c.w.) laser excitation.

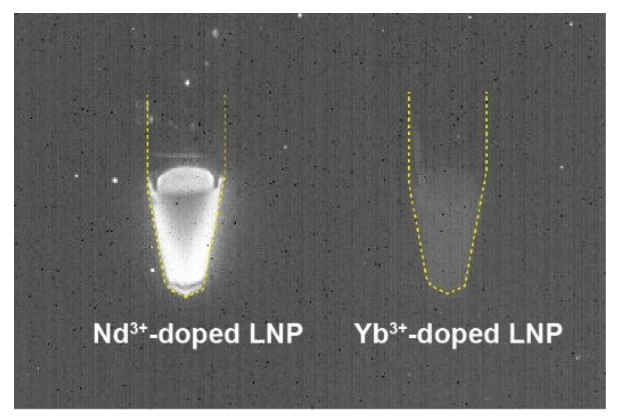

Figure S18. Fluorescence images of bare $\mathrm{Nd}^{3+}$-doped LNP $\left(600 \mu \mathrm{L}, 2 \mathrm{mg} \mathrm{mL}^{-1}\right)$ and $\mathrm{Yb}^{3+}$ doped LNP $\left(600 \mu \mathrm{L}, 2 \mathrm{mg} \mathrm{mL}^{-1}\right)$ under $808 \mathrm{~nm}(2 \mathrm{~W}$, c.w.) laser excitation. 
Determination of ions concentrations by ICP-MS. $2 \mu \mathrm{L}$ of the QD-sensitized LNP hybrid solution was added into $500 \mu \mathrm{L}$ of aqua regia $\left(\mathrm{HCl}: \mathrm{HNO}_{3}=3: 1, \mathrm{v} / \mathrm{v}\right)$, stirring overnight at room temperature. The final volume of solution was filled to $10 \mathrm{~mL}$ with DI water for ICP-MS analysis.

Determination the average surface density of $\operatorname{Ag}_{2} \mathrm{~S}$ QDs on the surface of LNP. First, we need to estimate the number of LNPs in QD-sensitized LNP hybrid solution. For this purpose, we assume a single LNP to be spherical with volume $\left(V_{L N P}\right)$ described by:

$$
V_{L N P}=\frac{4}{3} \pi r_{L N P}{ }^{3},
$$

where $r_{L N P}$ is the radius of the LNP. Since the LNP consists of hexagonal unit cells (Fig. S18), volume of a hexagonal unit cell $\left(u V_{h}\right)$ is described by:

$$
u V_{h}=\frac{2 \sqrt{3}}{4} a_{h}{ }^{2} c_{h}
$$

where $a_{h}$ and $c_{h}$ are lattice parameters of hexagonal unit cells (hexagonal lattice parameters $\left.a_{h}=0.596 \mathrm{~nm}, c_{h}=0.353 \mathrm{~nm}\right)$. Thus, the number of unit cells in an LNP can be given by:

$$
u N_{h}=V_{L N P} / u V_{h}
$$

This calculation are based on the assumption that the effects of crystal dislocations and rounding error in the total number of unit cells to be negligible, and that lattice parameters are accurate, as well as LNPs are composed of $100 \%$ hexagonal unit cells.

If no lanthanide ions were doped in LNPs, the Yttrium (Y) atomic weight of a single hexagonal $\mathrm{Na}_{1.5} \mathrm{Y}_{1.5} \mathrm{~F}_{6}$ unit cell $\left(u A W_{Y}\right)$ is described by:

$$
u A W_{Y}=1.5 \times A W_{Y},
$$

where $A W_{Y}$ is the atomic weight $\left(\mathrm{g} \mathrm{mol}^{-1}\right)$ of $\mathrm{Y}$. We assume any mass difference due to loss 
of electrons in ionisation to be negligible. Considering a fraction of $\mathrm{Y}^{3+}$ ions are substituted by lanthanide ions during $\mathrm{Er}^{3+}$-doped LNPs synthesis, we intrudce a factor $\left(f_{Y, L N P}\right)$ as the fractional percentage of $\mathrm{Y}^{3+}$ ions in $\mathrm{Er}^{3+}$-doped LNPs unit cells to describe the $\mathrm{Y}$ atomic weight of a single unit cell within $\mathrm{Er}^{3+}$-doped LNPs:

$$
u A W_{Y, L N P}=1.5 \times f_{Y, L N P} \times A W_{Y}
$$

According to eq 3 and 5, the average weight of $\mathrm{Y}^{3+}$ ions in a single $\mathrm{LNP}\left(W_{Y, L N P}\right)$ can be described by

$$
W_{Y, L N P}=1.5 \times f_{Y, L N P} \times A W_{Y} \times u N_{h}
$$

According to eq 6, the number of LNPs in QD-sensitized LNP system $\left(N_{L N P}\right)$ can be estimated as

$$
N_{L N P}=W_{Y, \text { system }} / W_{Y, L N P}
$$

where $W_{Y, \text { system }}$ is the weight of $\mathrm{Y}^{3+}$ ions in the total system that obtained by ICP-MS (Fig. S14).

Subsequently, we also estimate the number of $\mathrm{Ag}_{2} \mathrm{~S}$ QDs in QD-sensitized LNP system solution by the similar method. In this case, we assume $\mathrm{Ag}_{2} \mathrm{~S}$ QDs is spherical with a radius of $r_{Q D}$, and the volume of a single QD $\left(V_{Q D}\right)$ can be described by:

$$
V_{Q D}=\frac{4}{3} \pi r_{Q D}^{3}
$$

Considering the synthesized $\mathrm{Ag}_{2} \mathrm{~S}$ QDs belong to monoclinic crystal (Fig. S4), volume of a monoclinic unit cell $\left(u V_{m}\right)$ is given by:

$$
u V_{m}=a_{m} b_{m} c_{m} \sin \beta,
$$

where $a_{m}, b_{m}$ and $c_{m}$ are lattice parameters of monoclinic unit cells (monoclinic lattice parameters $a_{m}=0.423 \mathrm{~nm}, b_{m}=0.693 \mathrm{~nm}, c_{m}=0.786$, and $\left.\beta=99.61^{\circ}\right)$. Thus, the 
number of unit cells in a QD can be estimated by:

$$
u N_{m}=V_{Q D} / u V_{m}
$$

This calculation are also based on the assumption that the effects of crystal dislocations and rounding error in the total number of unit cells to be negligible, and that lattice parameters are accurate.

Accodring to the lattice parameters of $\mathrm{Ag}_{2} \mathrm{~S}$ QDs, the silver $(\mathrm{Ag})$ atomic weight of a single monoclinic $\mathrm{Ag}_{8} \mathrm{~S}_{4}$ unit cell $\left(u A W_{A g}\right)$ can be described by:

$$
u A W_{A g}=8 \times A W_{A g},
$$

where $A W_{A g}$ is the atomic weight $\left(\mathrm{g} \mathrm{mol}^{-1}\right)$ of $\mathrm{Ag}$.

According to eq 10 and 11, the average weight of $\mathrm{Ag}^{+}$ions in a single $\mathrm{QD}\left(W_{A g, Q D}\right)$ can be described by

$$
W_{A g, Q D}=8 \times A W_{A g} \times u N_{m}
$$

According to eq 12, the number of QDs in QD-sensitized LNP system $\left(N_{Q D}\right)$ can be calculated as

$$
N_{Q D}=W_{A g, s y s t e m} / W_{A g, Q D},
$$

where $W_{A g, \text { system }}$ is the weight of $\mathrm{Ag}^{+}$ions in the total system that obtained by ICP-MS (Fig. S17).

Finally, through combining the eq 7 and 13 , the average surface density of $\mathrm{Ag}_{2} \mathrm{~S}$ QDs on the surface of a single LNP can be estimated by

$$
\text { Density }=N_{Q D} / N_{L N P}
$$

Calculation of ion contents in the shell of LNPs. The molar content of two rare earth ions 
$\left(\mathrm{Y}^{3+}\right.$ and $\left.\mathrm{Yb}^{3+}\right)$ in the shell region of core-shell LNPs can be calculated by

$$
n_{s, i}=n_{c s, i}-n_{c, i}
$$

where $n_{c s, i}$ is the total molar content of rare earth ions $\left(i=\mathrm{Y}^{3+}\right.$ and $\left.\mathrm{Yb}^{3+}\right)$ in core-shell LNPs, $n_{c, i}$ and $n_{s, i}$ are the molar content of rare earth ions $\left(i=\mathrm{Y}^{3+}\right.$ and $\left.\mathrm{Yb}^{3+}\right)$ in the core and shell region of core-shell LNPs, respectively. The molar content of rare earth ions was determined by ICP-MS (Fig. S14-16).

According to the eq 15, the molar ratio of two rare earth ions $\left(\mathrm{Y}^{3+}\right.$ and $\left.\mathrm{Yb}^{3+}\right)$ in the shell region of core-shell LNPs can be calculated by

$$
Y \%=\frac{n_{s, Y}}{n_{s, Y}+n_{s, Y b}}
$$

and

$$
Y b \%=\frac{n_{s, Y b}}{n_{s, Y}+n_{s, Y b}}
$$

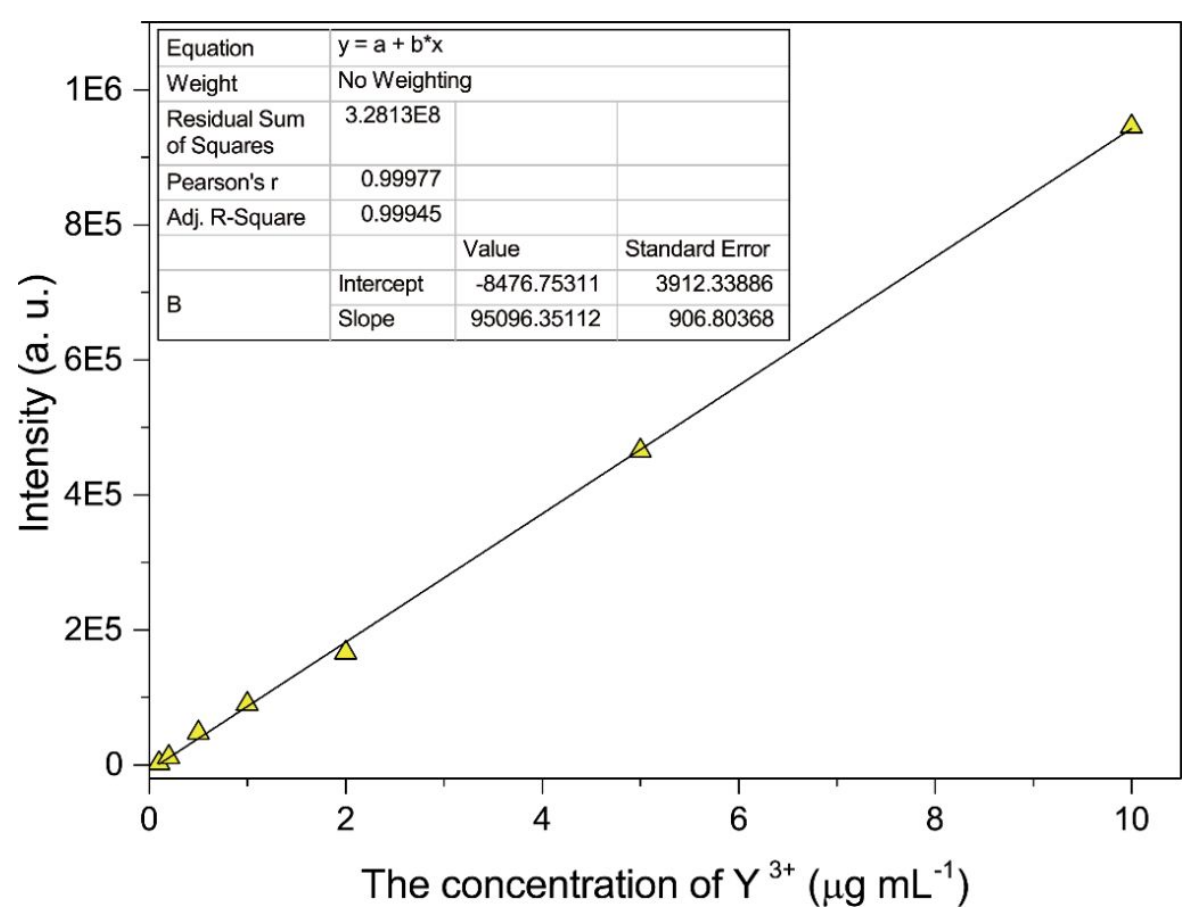

Figure S19. Working standard curve for quantification of the concentration of $\mathrm{Y}^{3+}$ ions. The Linearity of working standard curve for $\mathrm{Y}^{3+}$ ions was determined in the range of $0.1-10 \mu \mathrm{g}$ $\mathrm{mL}^{-1}$. 


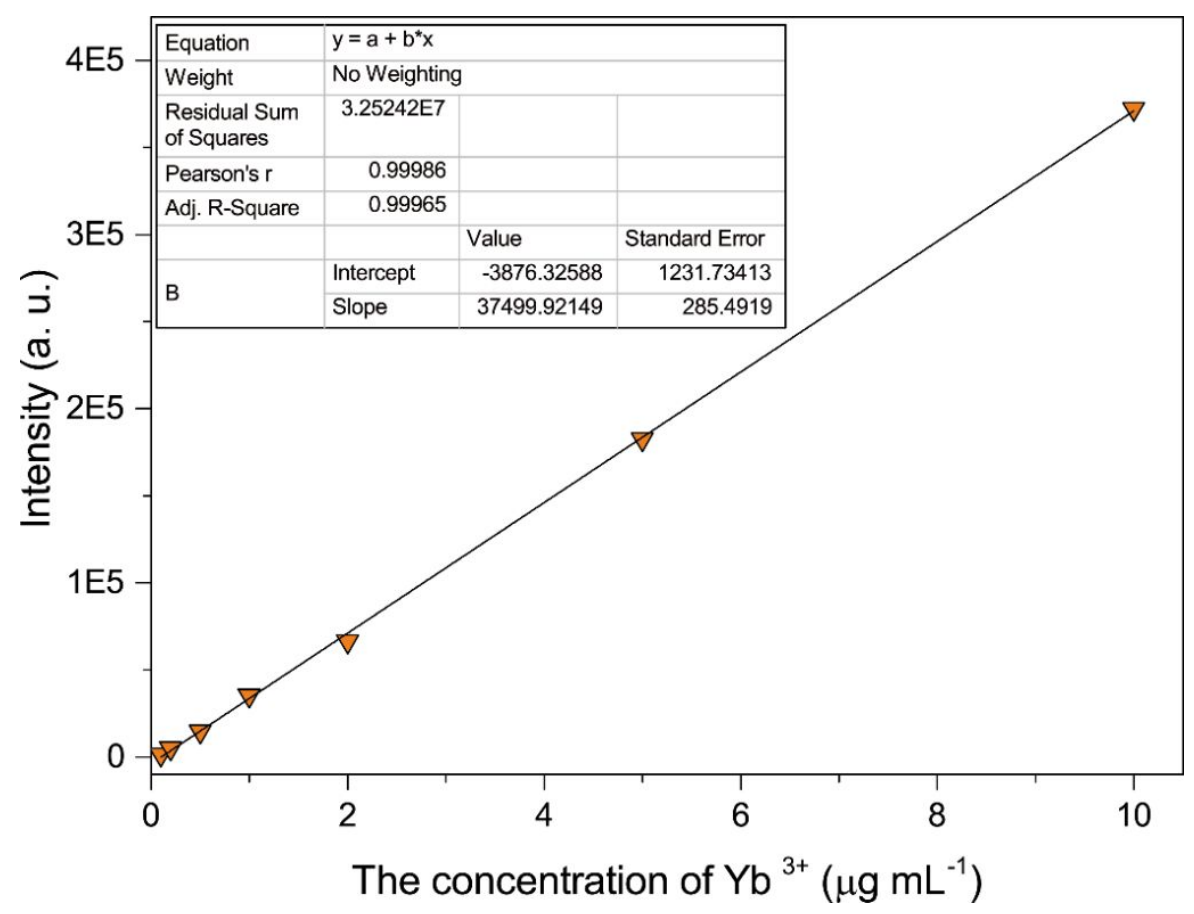

Figure S20. Working standard curve for quantification of the concentration of $\mathrm{Yb}^{3+}$ ions. The Linearity of working standard curve for $\mathrm{Yb}^{3+}$ ions was determined in the range of $0.1-10 \mu \mathrm{g}$ $\mathrm{mL}^{-1}$.

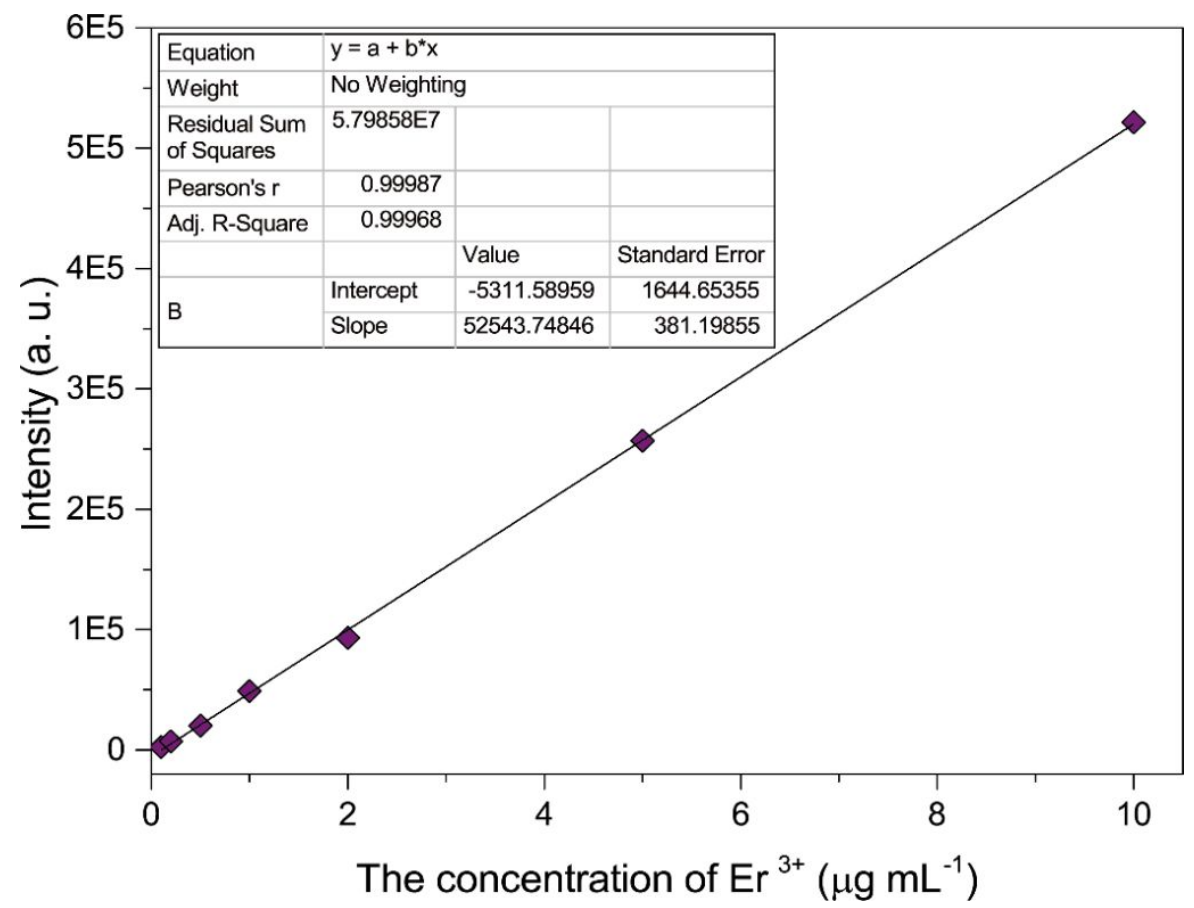

Figure S21. Working standard curve for quantification of the concentration of $\mathrm{Er}^{3+}$ ions. The Linearity of working standard curve for $\mathrm{Er}^{3+}$ ions was determined in the range of $0.1-10 \mu \mathrm{g}$ $\mathrm{mL}^{-1}$. 


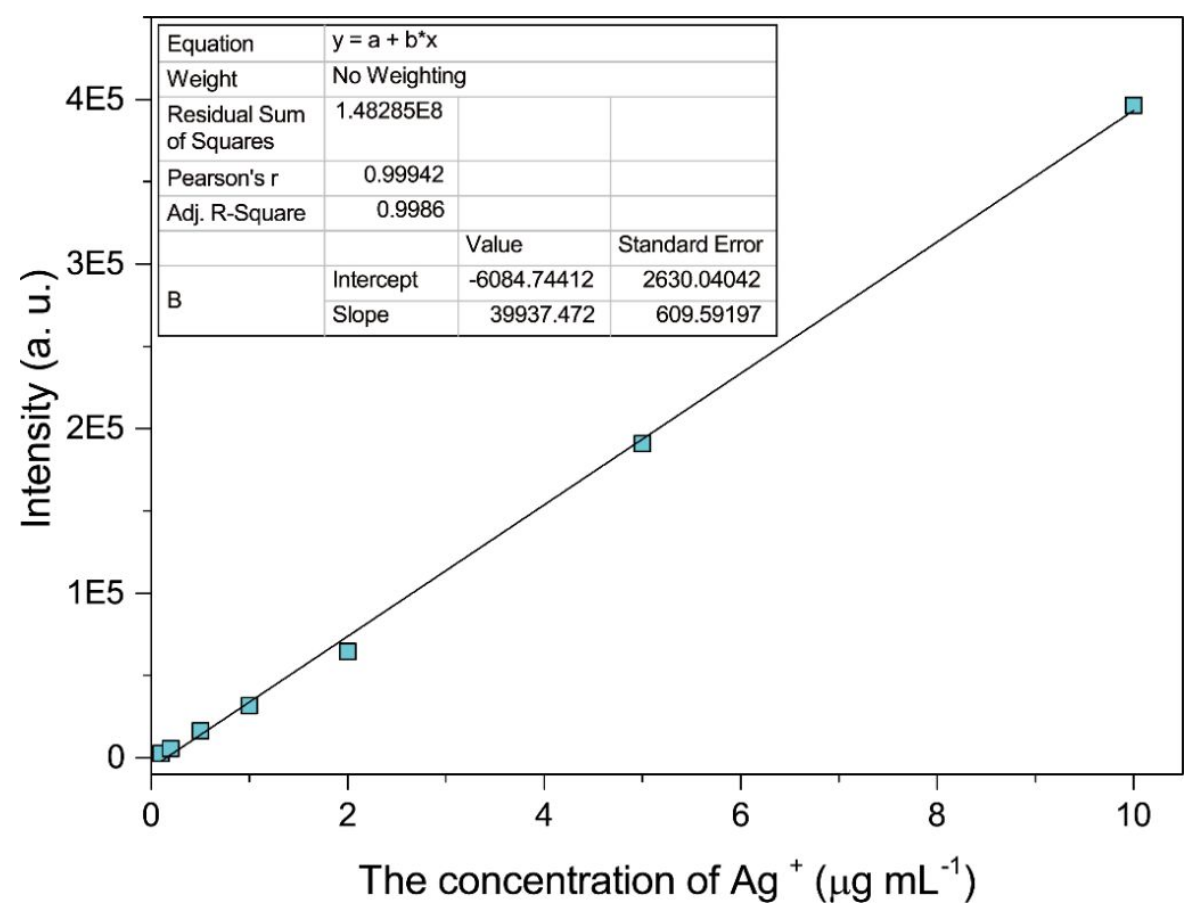

Figure S22. Working standard curve for quantification of the concentration of $\mathrm{Ag}^{+}$ions. The Linearity of working standard curve for $\mathrm{Ag}^{+}$ions was determined in the range of $0.1-10 \mu \mathrm{g}$ $\mathrm{mL}^{-1}$.

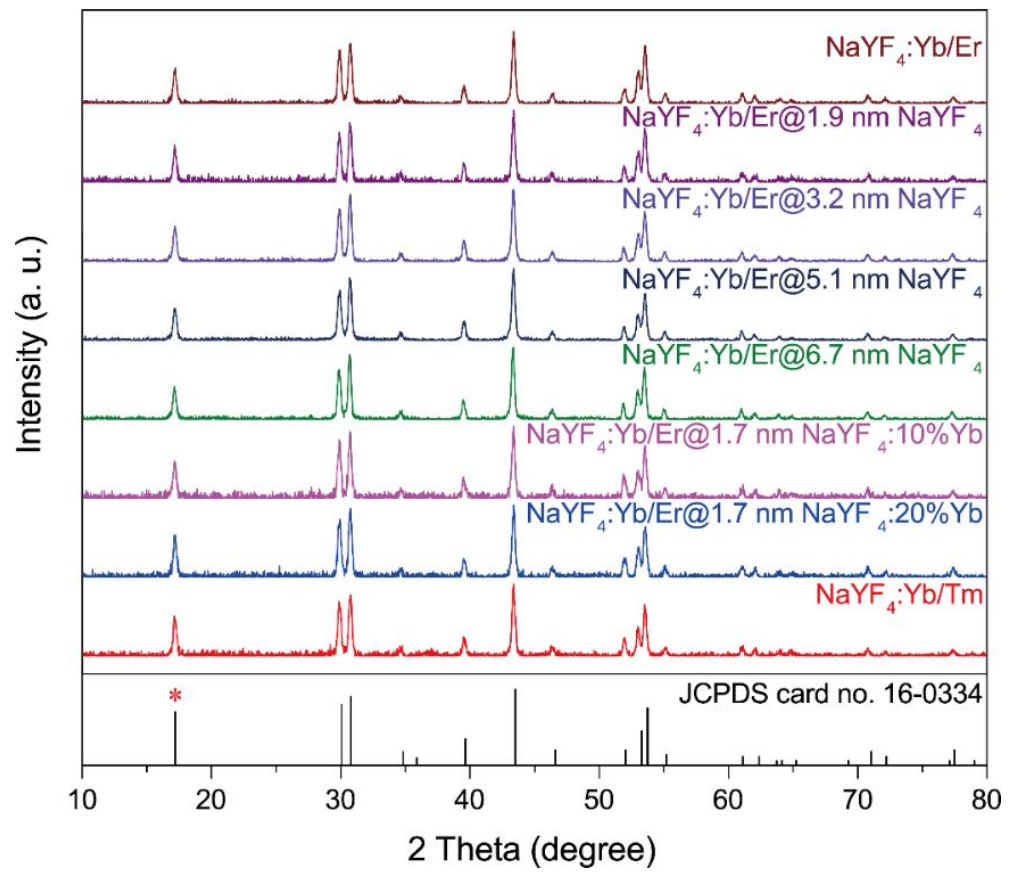

Figure S23. XRD patterns of core and core-shell LNPs. The result shows the position and relative intensity of diffraction peaks of all the synthesized core and core-shell LNPs were in accordance with those of standard $\mathrm{NaYF}_{4}$ (JCPDS card no. 16-0334). 
Synthesis of $\sim 32 \mathrm{~nm} \mathrm{NaY}{ }_{0.8} \mathrm{~F}_{4}: \mathrm{Yb}_{0.18}, \mathrm{Er}_{0.02}$ core with $\sim 1.9 \mathrm{~nm} \mathrm{NaYF}$ shell. An aqueous solution $(2 \mathrm{~mL})$ of $\mathrm{Y}\left(\mathrm{CH}_{3} \mathrm{CO}_{2}\right)_{3}(0.05 \mathrm{mmol})$ was added into a $50 \mathrm{~mL}$ three-necked flask containing OA $(3 \mathrm{ml})$ and $\mathrm{ODE}(7 \mathrm{ml})$. The mixture was heated to $160{ }^{\circ} \mathrm{C}$ for $1 \mathrm{~h}$, and then naturally cooled down to room temperature. After that $2 \mathrm{~mL}$ of the prepared $\sim 32 \mathrm{~nm}$ $\mathrm{NaY}_{0.8} \mathrm{~F}_{4}: \mathrm{Yb}_{0.18}, \mathrm{Er}_{0.02}$ core $(\sim 0.2 \mathrm{mmol})$ in cyclohexane was added along with $6 \mathrm{~mL}$ methanol solution containing $0.2 \mathrm{mmol} \mathrm{NH}_{4} \mathrm{~F}$ and $0.125 \mathrm{mmol} \mathrm{NaOH}$, the mixture was stirred for $30 \mathrm{~min}$ at $50{ }^{\circ} \mathrm{C}$. Subsequently, the temperature was increased to $110{ }^{\circ} \mathrm{C}$ to completely remove methanol from the mixture, and the resulting mixture was further heated to $300{ }^{\circ} \mathrm{C}$ for $1.5 \mathrm{~h}$ under an argon atmosphere. Then, the reaction mixture was naturally cooled down to room temperature. The obtained nanoparticles were precipitated by addition of ethanol, collected by centrifugation at $6000 \mathrm{rpm}$ for $10 \mathrm{~min}$, then washed with cyclohexane and ethanol several times, and finally dispersed in $2 \mathrm{~mL}$ of cyclohexane.

\section{Synthesis of $\sim 32 \mathrm{~nm} \mathrm{NaY}{ }_{0.8} \mathrm{~F}_{4}: \mathrm{Yb}_{0.18}, \mathrm{Er}_{0.02}$ core with $\sim 3.2 \mathrm{~nm}, \sim 5.1 \mathrm{~nm}$ and $\sim 6.7 \mathrm{~nm} \mathrm{NaYF} 4$}

shell. The procedure is identical to the synthesis of $\sim 32 \mathrm{~nm} \mathrm{NaY}{ }_{0.8} \mathrm{~F}_{4}: \mathrm{Yb}_{0.18}, \mathrm{Er}_{0.02}$ core with $\sim 1.9 \mathrm{~nm} \mathrm{NaYF}_{4}$ shell, except using an aqueous solution $(2 \mathrm{~mL})$ of $\mathrm{Y}\left(\mathrm{CH}_{3} \mathrm{CO}_{2}\right)_{3}(0.1 \mathrm{mmol})$ to replace the aqueous solution $(2 \mathrm{~mL})$ of $\mathrm{Y}\left(\mathrm{CH}_{3} \mathrm{CO}_{2}\right)_{3}(0.05 \mathrm{mmol})$, and methanol solution (6 $\mathrm{mL}$ ) containing $0.4 \mathrm{mmol} \mathrm{NH}_{4} \mathrm{~F}$ and $0.25 \mathrm{mmol} \mathrm{NaOH}$ to replace methanol $(6 \mathrm{~mL})$ solution containing $0.2 \mathrm{mmol} \mathrm{NH}_{4} \mathrm{~F}$ and $0.125 \mathrm{mmol} \mathrm{NaOH}$, respectively, for $\sim 32 \mathrm{~nm}$ $\mathrm{NaY}_{0.8} \mathrm{~F}_{4}: \mathrm{Yb}_{0.18}, \mathrm{Er}_{0.02}$ core with $\sim 3.2 \mathrm{~nm} \mathrm{NaY}{ }_{0.9} \mathrm{~F}_{4}: \mathrm{Yb}_{0.1}$ shell; using an aqueous solution $(2 \mathrm{~mL})$ of $\mathrm{Y}\left(\mathrm{CH}_{3} \mathrm{CO}_{2}\right)_{3}(0.15 \mathrm{mmol})$ to replace the aqueous solution $(2 \mathrm{~mL})$ of $\mathrm{Y}\left(\mathrm{CH}_{3} \mathrm{CO}_{2}\right)_{3}(0.05$ mmol), and methanol solution (6 mL) containing $0.6 \mathrm{mmol} \mathrm{NH}_{4} \mathrm{~F}$ and $0.375 \mathrm{mmol} \mathrm{NaOH}$ to replace methanol $(6 \mathrm{~mL})$ solution containing $0.2 \mathrm{mmol} \mathrm{NH}_{4} \mathrm{~F}$ and $0.125 \mathrm{mmol} \mathrm{NaOH}$, respectively, for $\sim 32 \mathrm{~nm} \mathrm{NaY}{ }_{0.8} \mathrm{~F}_{4}: \mathrm{Yb}_{0.18}, \mathrm{Er}_{0.02}$ core with $\sim 5.1 \mathrm{~nm} \mathrm{NaY} \mathrm{N}_{0.8} \mathrm{~F}_{4}: \mathrm{Yb}_{0.2}$ shell; and using an aqueous solution $(2 \mathrm{~mL})$ of $\mathrm{Y}\left(\mathrm{CH}_{3} \mathrm{CO}_{2}\right)_{3}(0.2 \mathrm{mmol})$ to replace the aqueous solution $(2 \mathrm{~mL})$ of $\mathrm{Y}\left(\mathrm{CH}_{3} \mathrm{CO}_{2}\right)_{3}(0.05 \mathrm{mmol})$, and methanol solution $(6 \mathrm{~mL})$ containing $0.8 \mathrm{mmol} \mathrm{NH}_{4} \mathrm{~F}$ and $0.5 \mathrm{mmol} \mathrm{NaOH}$ to replace methanol $(6 \mathrm{~mL})$ solution containing $0.2 \mathrm{mmol} \mathrm{NH}_{4} \mathrm{~F}$ and 0.125 mmol NaOH, respectively, for $\sim 32 \mathrm{~nm} \mathrm{NaY}_{0.8} \mathrm{~F}_{4}: \mathrm{Yb}_{0.18}, \mathrm{Er}_{0.02}$ core with $\sim 6.7 \mathrm{~nm} \mathrm{NaY}{ }_{0.8} \mathrm{~F}_{4}: \mathrm{Yb}_{0.2}$ shell. 

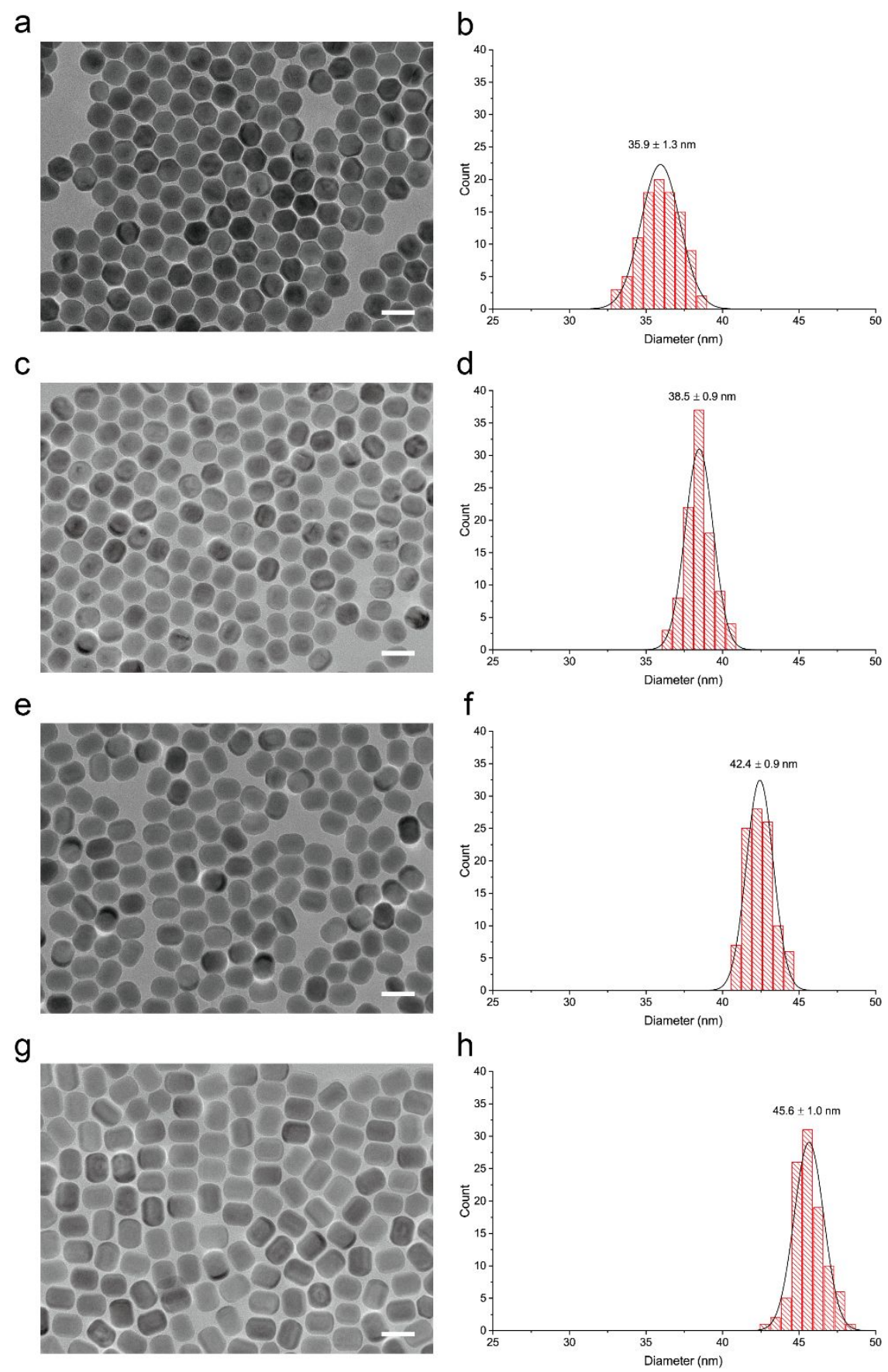

Figure S24. Characterization of the synthesized core-shell LNPs. a) TEM image of LNPs with $\sim 1.9 \mathrm{~nm}$ shell. b) Size distribution of LNPs with $\sim 1.9 \mathrm{~nm}$ shell. c) TEM image of LNPs with $\sim 3.2 \mathrm{~nm}$ shell. d) Size distribution of LNPs with $\sim 3.2 \mathrm{~nm}$ shell. e) TEM image of LNPs with $\sim 5.1 \mathrm{~nm}$ shell. f) Size distribution of LNPs with $\sim 5.1 \mathrm{~nm}$ shell. g) TEM image of LNPs with $\sim 6.7 \mathrm{~nm}$ shell. $\mathrm{h}$ ) Size distribution of LNPs with $\sim 6.7 \mathrm{~nm}$ shell. Scale bar, $50 \mathrm{~nm}$. 
Synthesis of $\sim 32 \mathrm{~nm} \mathrm{NaY} \mathbf{0 . 8}_{4} \mathrm{~F}_{4}: \mathrm{Yb}_{0.18}, \mathrm{Er}_{0.02}$ core with $\sim 1.7 \mathrm{~nm} \mathrm{NaY} \mathrm{Nix}_{4} \mathrm{~F}_{4}: \mathrm{Yb}_{\mathrm{x}}(\mathrm{x}=0.1,0.2)$

shell. The procedure is identical to the synthesis of $\sim 32 \mathrm{~nm} \mathrm{NaY}{ }_{0.8} \mathrm{~F}_{4}: \mathrm{Yb}_{0.18}, \mathrm{Er}_{0.02}$ core with

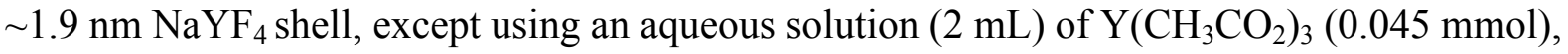
$\mathrm{Yb}\left(\mathrm{CH}_{3} \mathrm{CO}_{2}\right)_{3}(0.005 \mathrm{mmol})$ to replace the aqueous solution $(2 \mathrm{~mL})$ of $\mathrm{Y}\left(\mathrm{CH}_{3} \mathrm{CO}_{2}\right)_{3}(0.05$ mmol) for $\sim 32 \mathrm{~nm} \mathrm{NaY}{ }_{0.8} \mathrm{~F}_{4}: \mathrm{Yb}_{0.18}, \mathrm{Er}_{0.02}$ core with $\sim 1.7 \mathrm{~nm} \mathrm{NaY}{ }_{0.9} \mathrm{~F}_{4}: \mathrm{Yb}_{0.1}$ shell, and using an aqueous solution $(2 \mathrm{~mL})$ of $\mathrm{Y}\left(\mathrm{CH}_{3} \mathrm{CO}_{2}\right)_{3}(0.04 \mathrm{mmol}), \mathrm{Yb}\left(\mathrm{CH}_{3} \mathrm{CO}_{2}\right)_{3}(0.01 \mathrm{mmol})$ to replace the aqueous solution $(0.2 \mathrm{~mL})$ of $\mathrm{Y}\left(\mathrm{CH}_{3} \mathrm{CO}_{2}\right)_{3}(0.05 \mathrm{mmol})$ for $\sim 32 \mathrm{~nm} \mathrm{NaY}{ }_{0.8} \mathrm{~F}_{4}: \mathrm{Yb}_{0.18}, \mathrm{Er}_{0.02}$ core with $\sim 1.7 \mathrm{~nm} \mathrm{NaY}{ }_{0.8} \mathrm{~F}_{4}: \mathrm{Yb}_{0.2}$ shell, respectively.

a

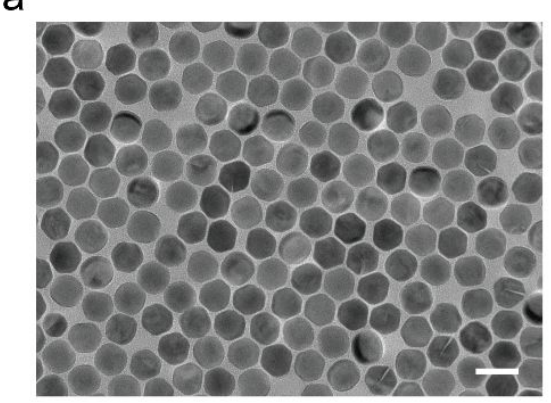

C

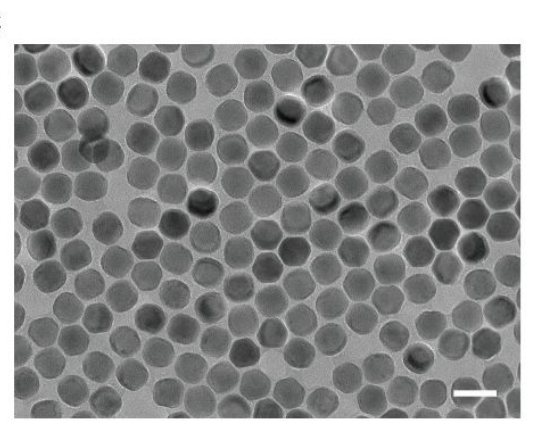

e

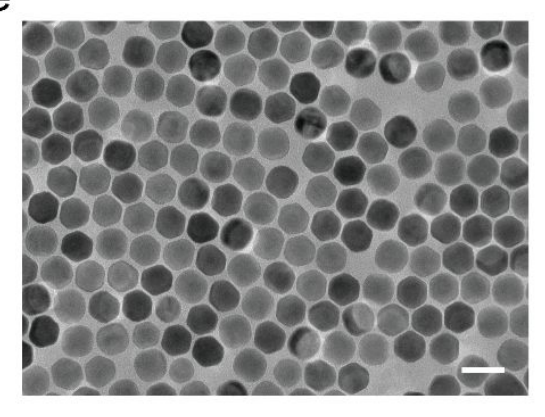

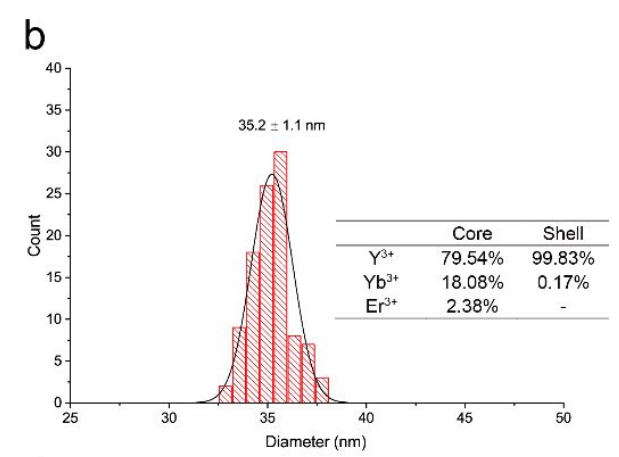
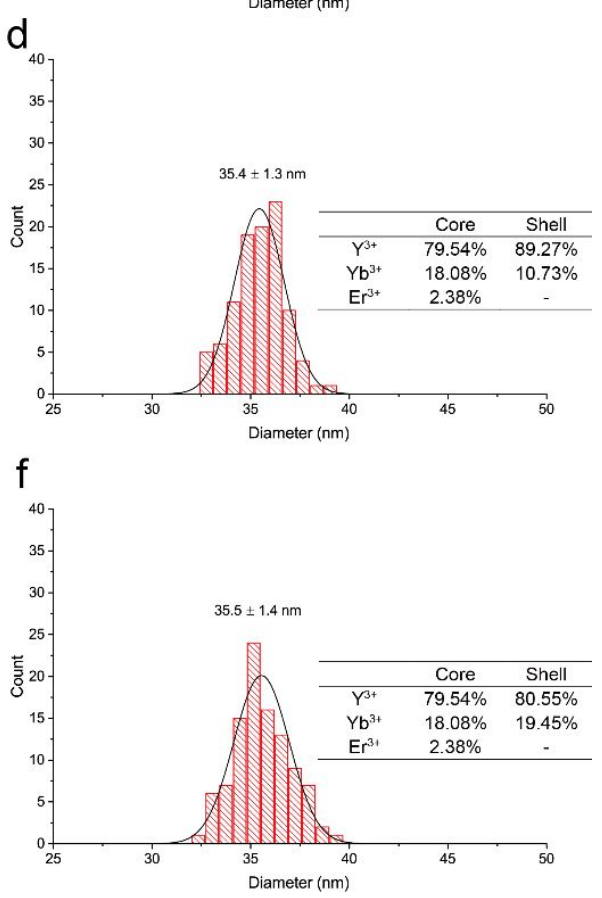

Figure S25. Characterization of the synthesized core LNPs with $\mathrm{Yb}^{3+}$ doping shell. a) TEM image of LNPs with $\mathrm{NaYF}_{4}$ shell. b) Size distribution of LNPs with $\mathrm{NaYF}_{4}$ shell. c) TEM image of LNPs with $10 \% \mathrm{Yb}^{3+}$ doping $\mathrm{NaYF}_{4}$ shell. d) Size distribution of LNPs with $10 \%$ $\mathrm{Yb}^{3+}$ doping $\mathrm{NaYF}_{4}$ shell. e) TEM image of LNPs with $20 \% \mathrm{Yb}^{3+}$ doping $\mathrm{NaYF}_{4}$ shell. f) Size distribution of LNPs with $20 \% \mathrm{Yb}^{3+}$ doping $\mathrm{NaYF}_{4}$ shell. Scale bar, $50 \mathrm{~nm}$. 


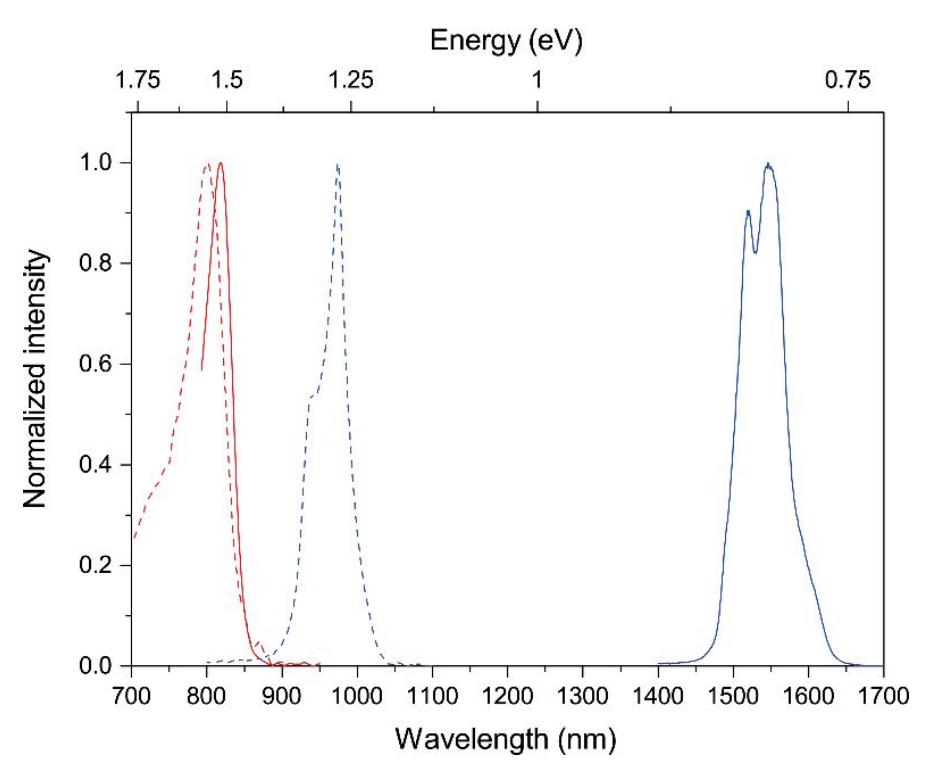

Figure S26. Fluorescence and absorption spectra of IR-806 dye and $\mathrm{Er}^{3+}$-doped LNPs. Spectra from left to right: IR-806 adsorption (dashed red line), IR-806 fluorescence (solid red line) at $808 \mathrm{~nm}$ (2 W, c.w.) laser excitation, $\mathrm{Er}^{3+}$-doped LNPs absorption (dashed blue line) and $\mathrm{Er}^{3+}$ doped LNPs fluorescence (solid blue line) at $980 \mathrm{~nm}(2 \mathrm{~W}, \mathrm{c.w}$.$) laser excitation.$

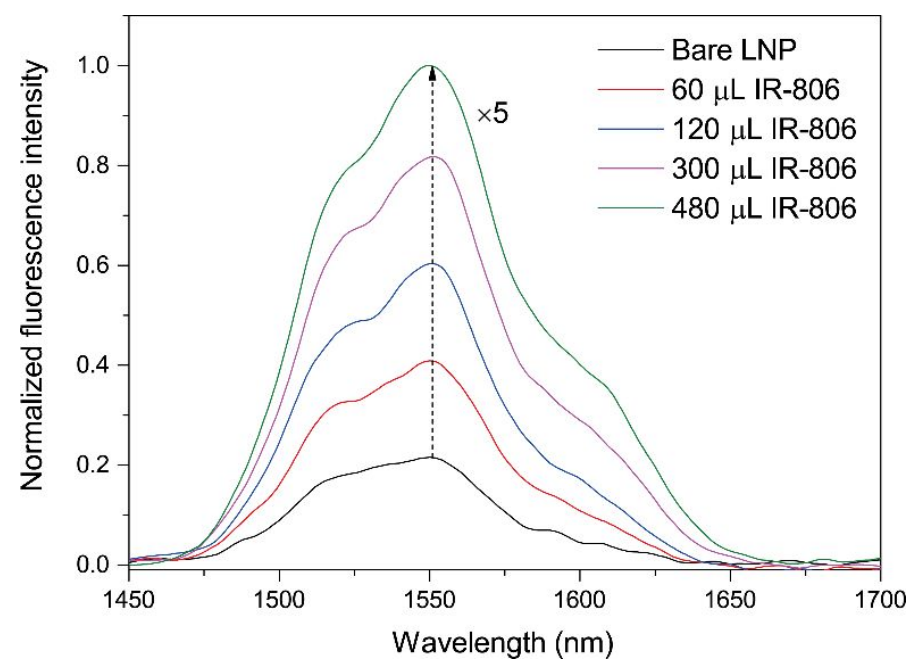

Figure S27. Fluorescence spectra of dye-sensitized $\mathrm{Er}^{3+}$-doped LNP system. With increasing amounts of IR-806 dye $\left(0.1 \mu \mathrm{g} \mathrm{mL} \mathrm{m}^{-1}\right)$, the emission intensity of $\mathrm{Er}^{3+}$-doped LNPs $(60 \mu \mathrm{L}, 20$ $\left.\mathrm{mg} \mathrm{mL} \mathrm{m}^{-1}\right)$ increased under $808 \mathrm{~nm}(2 \mathrm{~W}$, c.w. ) laser excitation. 


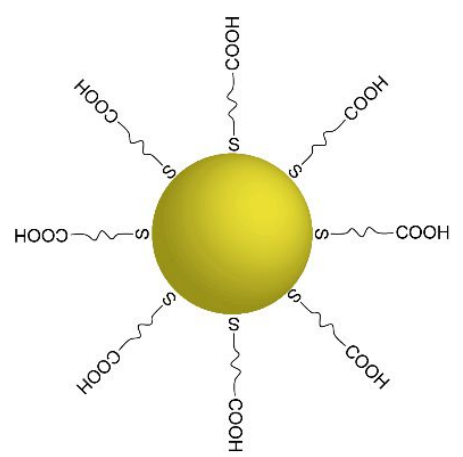

$\mathrm{Ag}_{2} \mathrm{~S} \mathrm{QDs} @ \mathrm{COOH}$

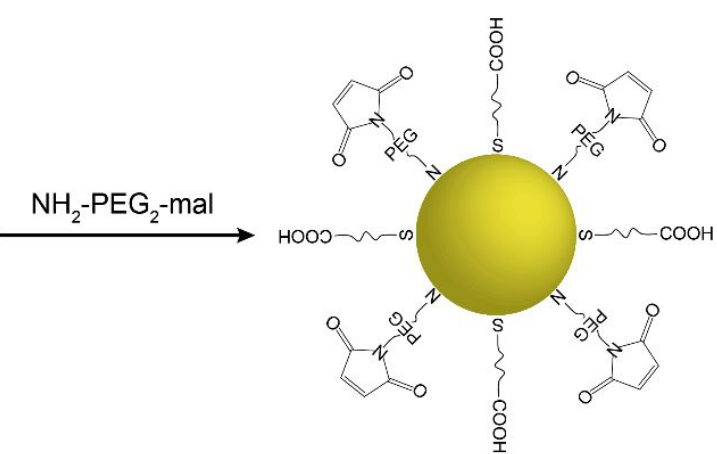

$\mathrm{Ag}_{2} \mathrm{~S}$ QDs@mal

Figure S28. Illustration of preparation scheme for $\mathrm{Ag}_{2} \mathrm{~S}$ QDs@mal.

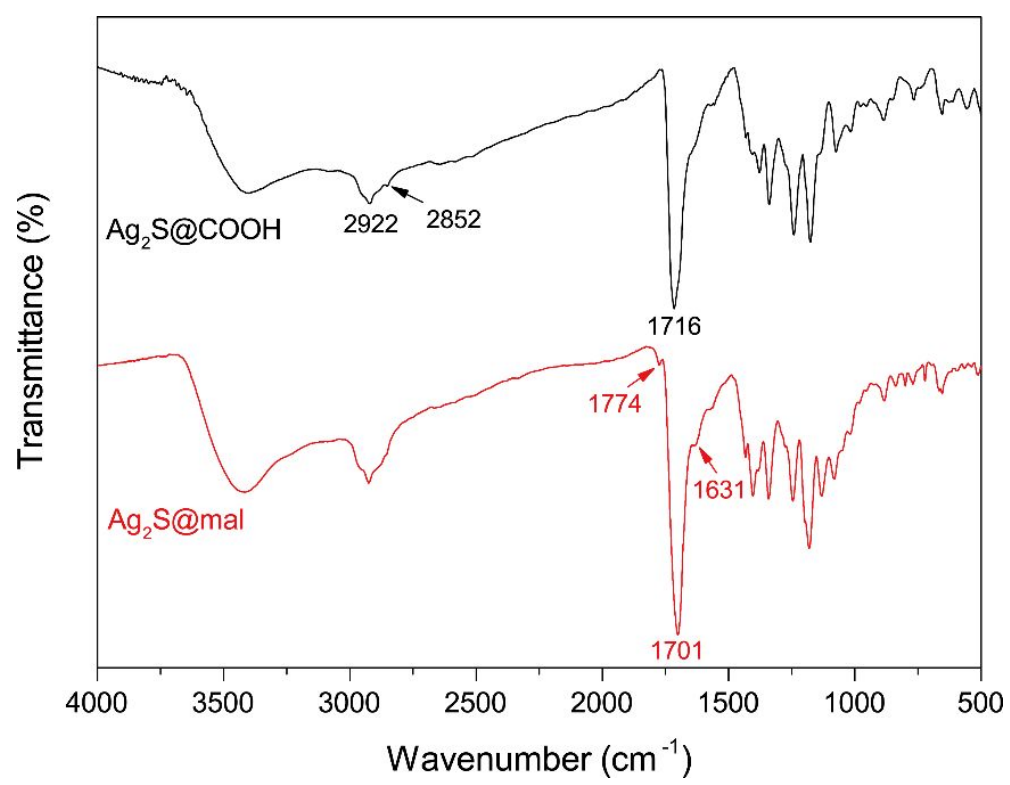

Figure S29. FI-TR spectrum of the synthesized $\mathrm{Ag}_{2} \mathrm{~S}$ QDs@mal. The typical bands at 2922 $\mathrm{cm}^{-1}$ and $2852 \mathrm{~cm}^{-1}$ are assigned to the asymmetric and symmetric stretching vibrations of C$\mathrm{H}$ of MPA. The sharp and strong band at $1716 \mathrm{~cm}^{-1}$ is assigned to the $\mathrm{C}=\mathrm{O}$ stretching vibrations of carboxylic acid group. After react with $\mathrm{NH}_{2}-\mathrm{PEG}_{2}$-maleimide, the new bands at $1631 \mathrm{~cm}^{-1}$ ( $\mathrm{C}=\mathrm{C}$ vibrations), $1774 \mathrm{~cm}^{-1}$ and $1701 \mathrm{~cm}^{-1}(\mathrm{C}=\mathrm{O}$ vibrations) correspond to the characteristic bands of maleimide group. The results confirm the successful preparation of $\mathrm{Ag}_{2} \mathrm{~S}$ QDs@mal. 


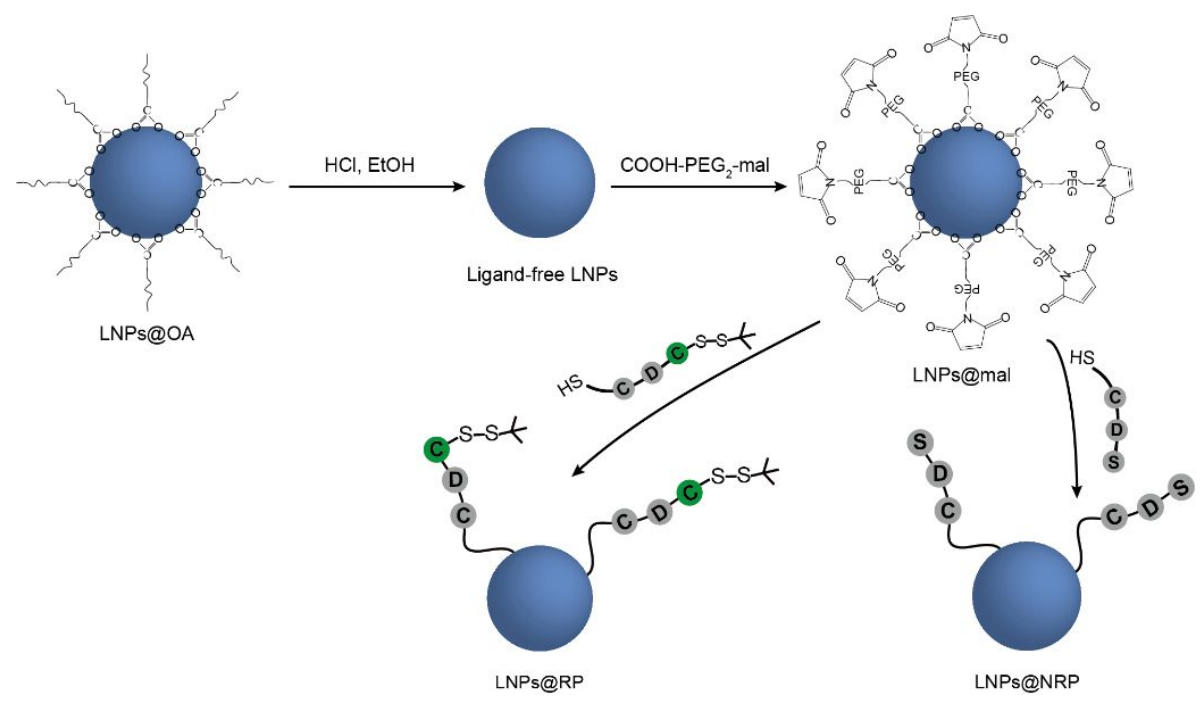

Figure S30. Illustration of preparation scheme for LNPs@RP.

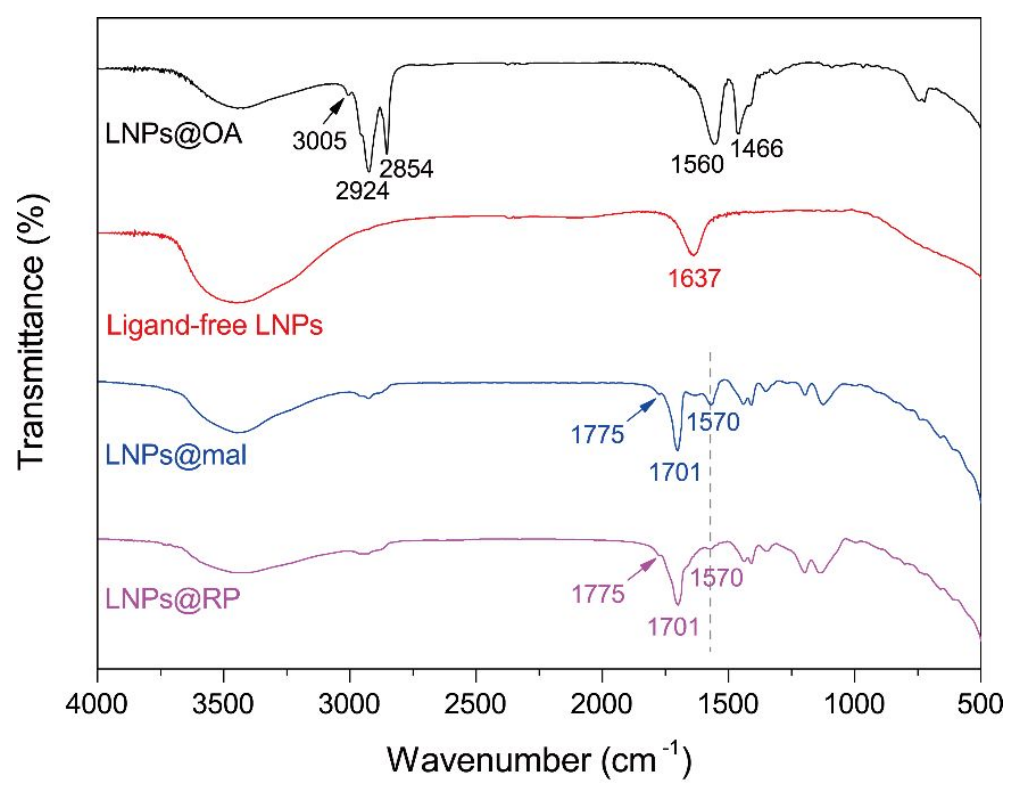

Figure S31. FI-TR spectrum of the synthesized LNPs@RP. The results show the characteristic bands of oleic acid at $3005 \mathrm{~cm}^{-1}$ (C-H stretch in $\left.\mathrm{C}=\mathrm{C}-\mathrm{H}\right), 2924 \mathrm{~cm}^{-1}$ and $2854 \mathrm{~cm}^{-1}\left(\mathrm{CH}_{2}\right.$ asymmetric and symmetric stretch), $1560 \mathrm{~cm}^{-1}$ and $1466 \mathrm{~cm}^{-1}$ (COO- asymmetric and symmetric stretch) disappear after $\mathrm{HCl}$ treatment. After react with $\mathrm{COOH}-\mathrm{PEG}_{2}$-maleimide, the new bands at $1570 \mathrm{~cm}^{-1}\left(\mathrm{C}=\mathrm{C}\right.$ vibrations), $1775 \mathrm{~cm}^{-1}$ and $1701 \mathrm{~cm}^{-1}(\mathrm{C}=\mathrm{O}$ vibrations $)$ correspond to the characteristic bands of maleimide group. When further covalently attach a peptide sequence, the relative intensity of band at $1570 \mathrm{~cm}^{-1}$ decreased, which confirms the successful preparation of LNPs@RP. 


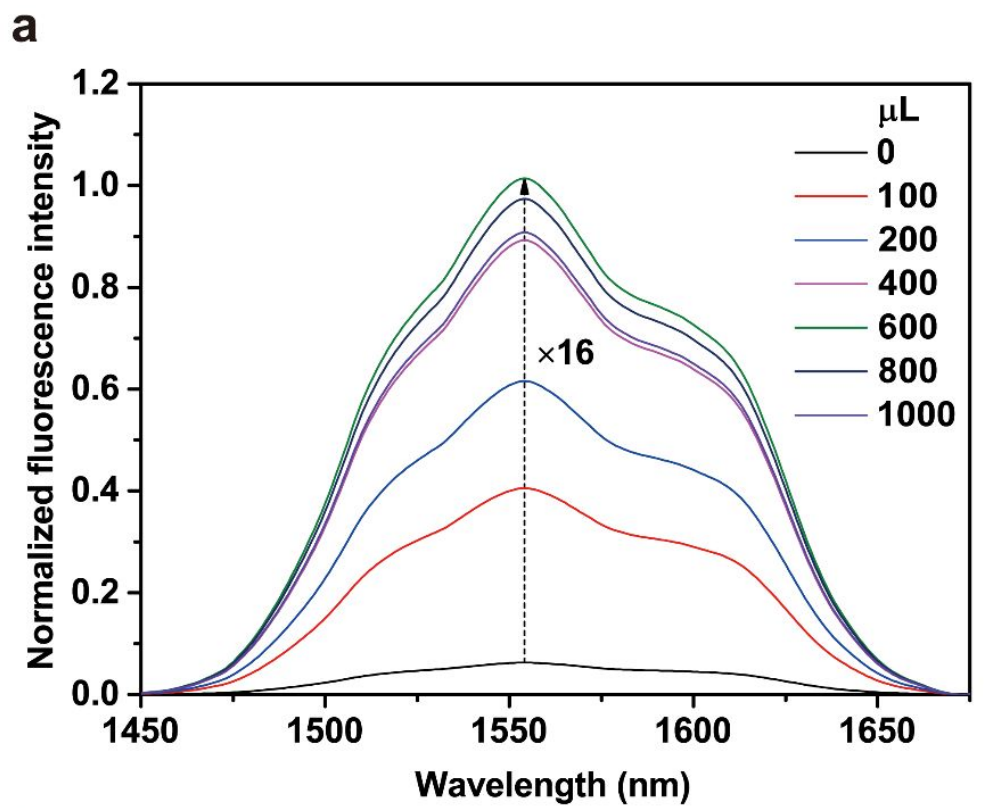

b

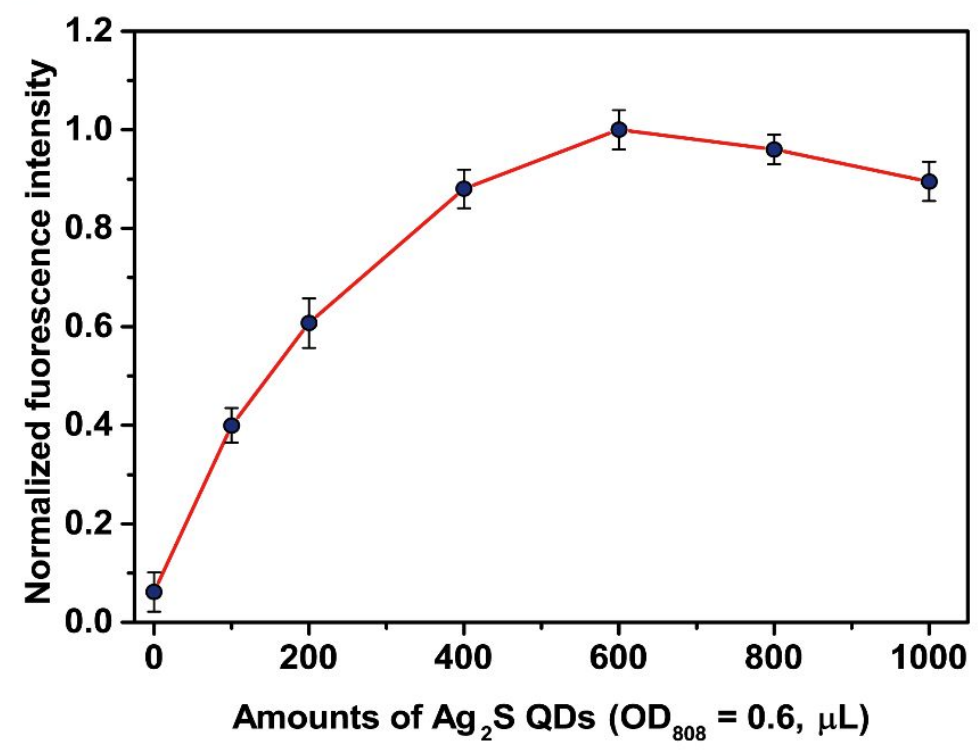

Figure S32. Ex vivo fluorescence spectra based on QD-sensitized LNP system upon GSH treatment. (a) Fluorescence spectra of LNPs@RP $\left(60 \mu \mathrm{L}, 20 \mathrm{mg} \mathrm{mL}^{-1}\right)$ with different amounts of $\mathrm{Ag}_{2} \mathrm{~S}$ QDs@mal $\left(0-1000 \mu \mathrm{L}, \mathrm{OD}_{808}=0.6\right)$ upon the addition of GSH solution $(10 \mu \mathrm{L}, 1.0$ M) at $808 \mathrm{~nm}(2 \mathrm{~W}$, c.w.) laser excitation. (b) Histogram analysis of fluorescence intensity changes in (a). 
For investigating the tumor retention kinetic of $\mathrm{Ag}_{2} \mathrm{~S} @$ mal QDs, $400 \mu \mathrm{L}$ of $\mathrm{Ag}_{2} \mathrm{~S} @$ mal QDs $\left(\mathrm{OD}_{808}=3.0\right)$ was intravenously injected into the tumor-bearing mouse, and in vivo imaging was performed under a $808 \mathrm{~nm}$ diode laser excitation light with a band pass filter (1000$1100 \mathrm{~nm})$.

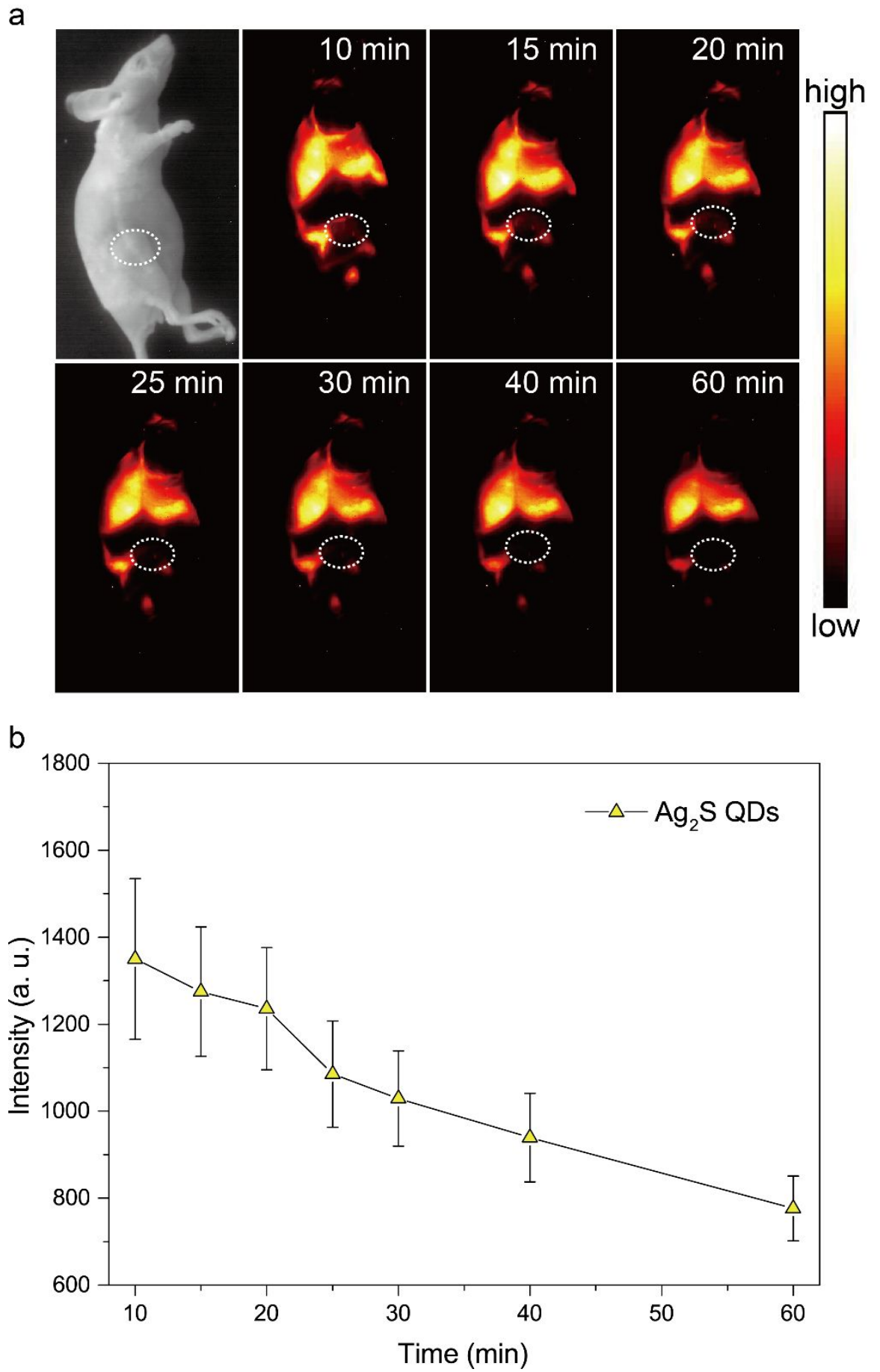

Figure S33. Tumor retention kinetics of $\mathrm{Ag}_{2} \mathrm{~S} @$ mal QDs. The result shows the maximum signal intensity of $\mathrm{Ag}_{2} \mathrm{~S}$ QDs in the tumor area is $\sim 10 \mathrm{~min}$ of post-injection. 
For investigating the tumor retention kinetic of LNPs@RP, $200 \mu \mathrm{L}$ of LNPs@RP(20 mg $\mathrm{mL}^{-1}$ ) was intravenously injected into the tumor-bearing mouse, and in vivo imaging was performed under a $980 \mathrm{~nm}$ diode laser excitation light with a band pass filter (1500-1600 $\mathrm{nm})$.

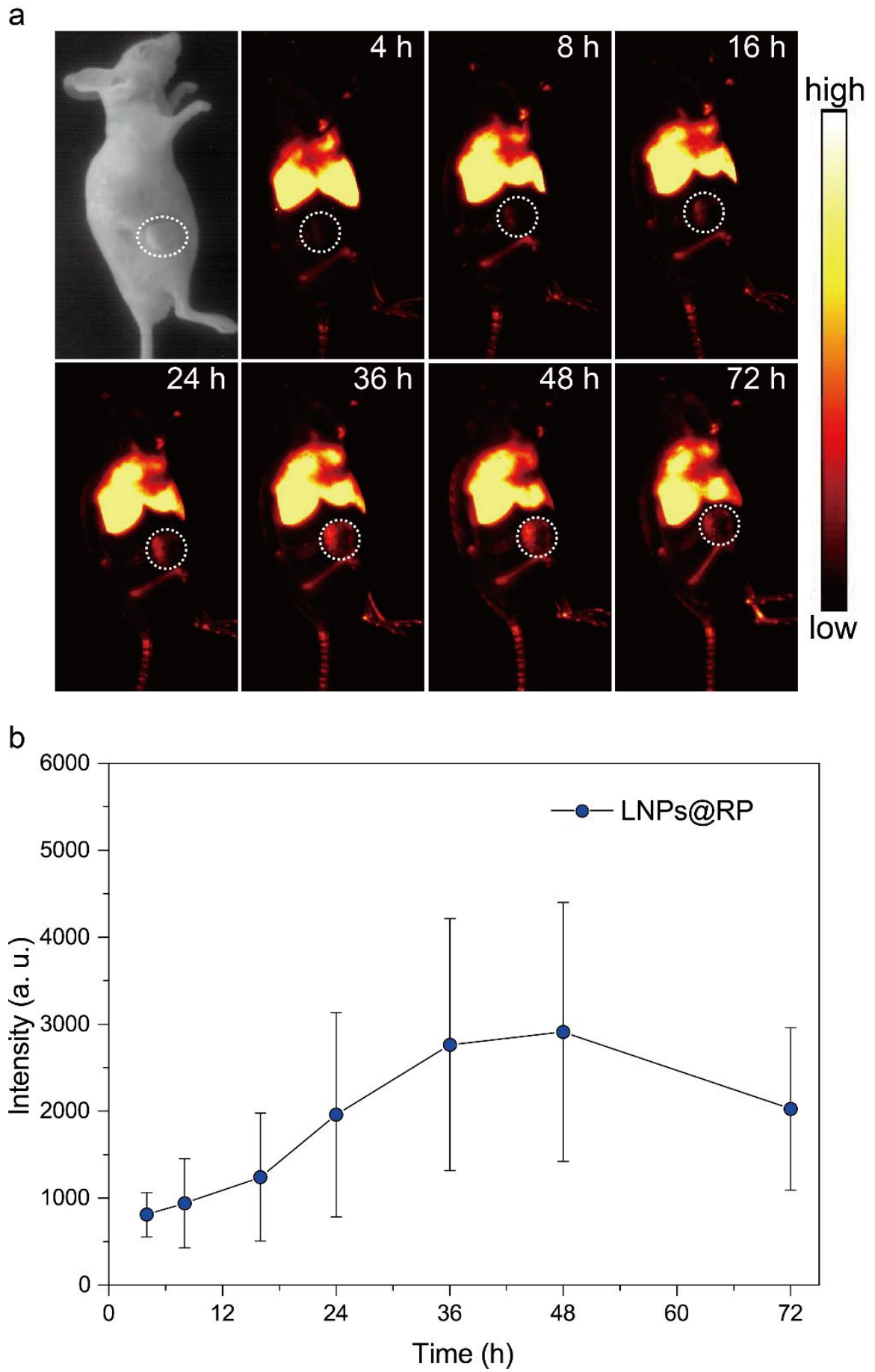

Figure S34. Tumor retention kinetics of LNPs@RP. The result shows the maximum signal intensity of LNPs@RP in the tumor area is $\sim 36$ h of post-injection. 
Synthesis of PbS QDs. $1 \mathrm{~mL}$ of $\mathrm{Pb}\left(\mathrm{CH}_{3} \mathrm{CO}_{2}\right)_{2}$ aqueous solution $(0.1 \mathrm{M})$ and $2 \mathrm{~mL}$ of $\mathrm{GSH}$ aqueous solution $(0.1 \mathrm{M})$ were added into $25 \mathrm{~mL}$ of deionized water in a $50 \mathrm{~mL}$ round bottom flask under argon atmosphere. The $\mathrm{pH}$ of the reaction solution was adjusted with $\mathrm{NaOH}$ aqueous solution (1.0 M). Subsequently, $0.1 \mathrm{~mL}$ of $\mathrm{Na}_{2} \mathrm{~S}$ aqueous solution $(0.1 \mathrm{M})$ was slowly added with a small volume syringe. The color of solution immediately turned to clear brown, indicate the formation of $\mathrm{PbS}$ QDs. The obtained $\mathrm{PbS}$ QDs was stored at $4{ }^{\circ} \mathrm{C}$ in the dark for further use.

\section{a}
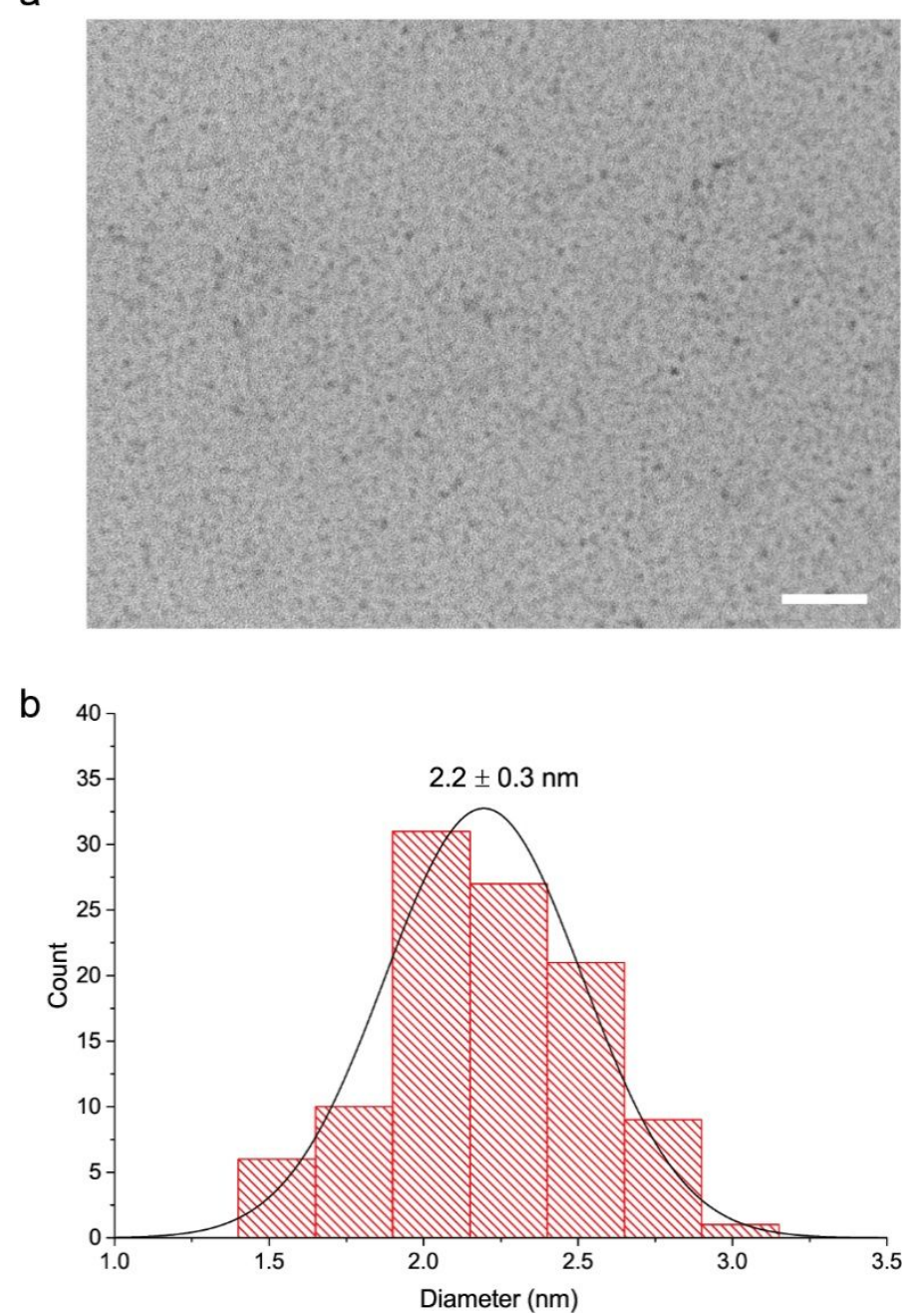

Figure S35. Characterization of the synthesized PbS QDs. a) TEM image of the synthesized $\mathrm{PbS}$ QDs. Scale bar, $25 \mathrm{~nm}$. b) Size distribution of the synthesized PbS QDs. 


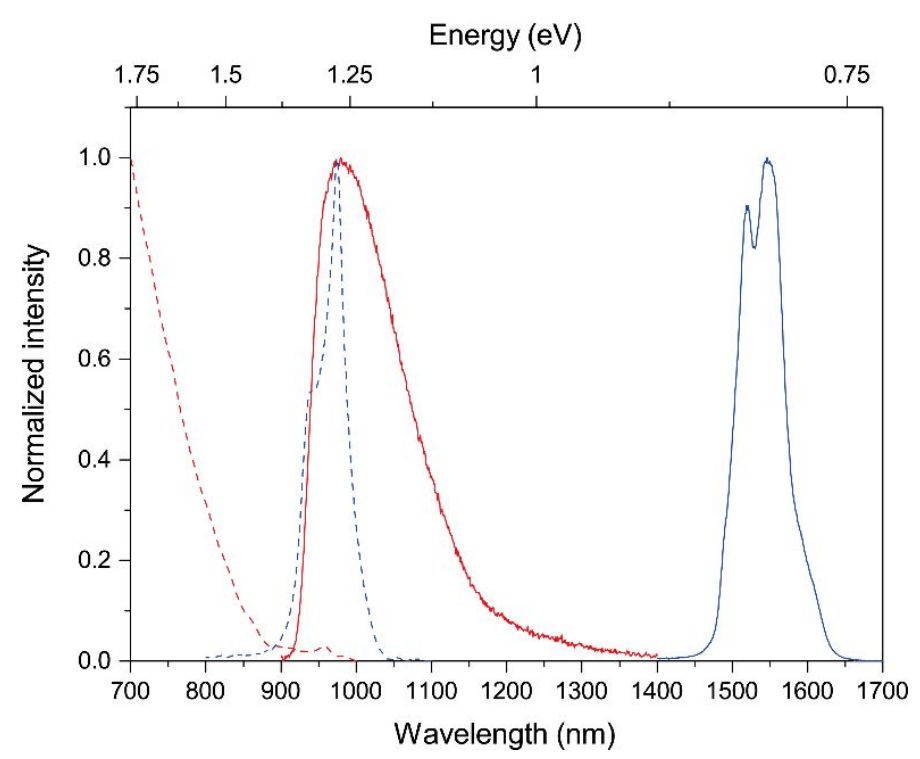

Figure S36. Fluorescence and absorption spectra of PbS QDs and $\mathrm{Er}^{3+}$-doped LNPs. Spectra from left to right: $\mathrm{PbS}$ QDs adsorption (dashed red line), $\mathrm{PbS}$ QDs fluorescence (solid red line) at $808 \mathrm{~nm}\left(2 \mathrm{~W}\right.$, c.w.) laser excitation, $\mathrm{Er}^{3+}$-doped LNPs absorption (dashed blue line) and $\mathrm{Er}^{3+}$ doped LNPs fluorescence (solid blue line) at $980 \mathrm{~nm}(2 \mathrm{~W}$, c.w.) laser excitation.

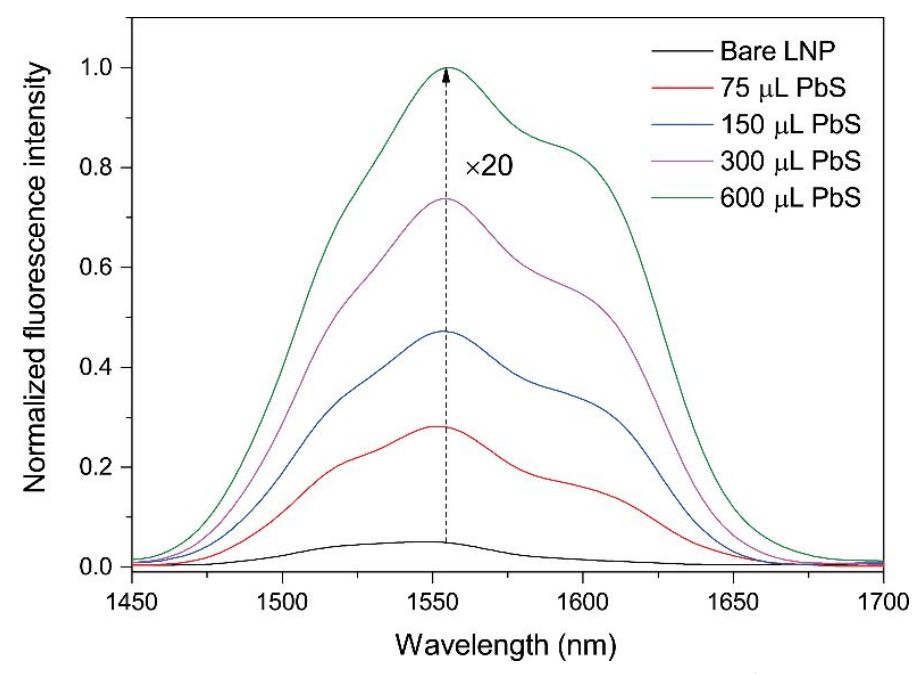

Figure S37. Fluorescence spectra of $\mathrm{PbS}$ QD-sensitized $\mathrm{Er}^{3+}$-doped LNP system. With increasing amounts of PbS QDs $\left(\mathrm{OD}_{808}=0.6\right)$, the emission intensity of $\mathrm{Er}^{3+}$-doped LNPs $(60$ $\left.\mu \mathrm{L}, 20 \mathrm{mg} \mathrm{mL}^{-1}\right)$ increased under $808 \mathrm{~nm}(2 \mathrm{~W}$, c.w.) laser excitation. Quantum yield of $\mathrm{PbS}$ QDs is $\sim 16 \%$. 